\title{
Cross-National Cultural Diffusion: The Global Spread of Cricket
}

\author{
Jason Kaufman \\ Harvard University
}

\author{
Orlando Patterson \\ Harvard University
}

This article explores the dynamics of cross-national cultural diffusion through the study of a case in which a symbolically powerful cultural practice, the traditionally English sport of cricket, successfully diffused to most but not all countries with close cultural ties to England. Neither network ties, nor national values, nor climatic conditions account for this disparity. Our explanation hinges instead on two key factors: first, the degree to which elites chose either to appropriate the game and deter others from participating or actively to promote it throughout the population for hegemonic purposes; and second, the degree to which the game was "popularized" by cultural entrepreneurs looking to get and keep spectators and athletes interested in the sport. Both outcomes relate to the nature of status hierarchies in these different societies, as well as the agency of elites and entrepreneurs in shaping the cultural valence of the game. The theoretical significance of this project is thus the observation that the diffusion of cultural practices can be promoted or discouraged by intermediaries with the power to shape the cultural meaning and institutional accessibility of such practices.

$\mathrm{W}$ hy do some foreign practices take root while others either arrive dead in the water or take hold only to wither and die? Modern diffusion studies have focused primarily on the structural aspects of diffusion, or the existence of tangible points of contact

Direct all correspondence to Jason Kaufman, Department of Sociology, 648 William James Hall, Harvard University, Cambridge, MA, 02138 (jkaufman@wjh.harvard.edu), or to Orlando Patterson, Department of Sociology, 520 William James Hall, Harvard University, Cambridge, MA, 02138 (op@wjh.harvard.edu). The authors thank Joel Ngugi and Michael Nguyen for their extraordinary efforts as research assistants. Cynthia Rockwell and Mary Quigley provided invaluable clerical assistance. The staff at the National Library of Canada was both helpful and accommodating. Andy Markovits provided information and inspiration for our own endeavor into "American exceptionalism" and the sociology of sport. Peter Moskos helped with baseball history. The authors also thank Jerry A. Jacobs and the editorial staff at $A S R$, as well as Michèle Lamont, Frank Dobbin, Chris Winship, and the members of the Culture Brown-Bag group at Harvard for their critical feedback on earlier drafts of this manuscript. between adopters and adoptees, as well as the environmental contexts that modulate such interactions. But as Strang and Soule (1998:276) note, "[S]tructural opportunities for meaningful contact cannot tell us what sorts of practices are likely to diffuse," whereas an "analysis of the cultural bases of diffusion speaks more directly to what spreads, replacing a theory of connections with a theory of connecting." According to this more culturally minded approach, diffusing practices are most likely to be adopted when they are first made congruent with local cultural frames or understandings, and are thus "rendered salient, familiar and compelling" (Strang and Soule 1998:276; see also Gottdiener 1985; Rogers 1995). In other cases, however, more than just "congruence" is needed for successful adoption; institutional support, repeated exposure, and/or active instruction in the new practice are required for it to "take hold" in new settings. The original cultural profile of that practice is often transformed in the process (e.g., Appadurai 1996; Bhabha 1994; Guillén 2001; Watson 2002). Sometimes, moreover, it is the very difference in social, cultural, and political power between change agents 
and adopters that accounts for successful longterm diffusion.

One case that encompasses all of these factors is the cross-national diffusion of cricket. Cricket originated in England as an informal rural game, though it quickly emerged into a highly competitive sport. Over time, cricket evolved into an English national pastime, along with soccer, rugby, and horse racing (Allen 1990). Cricket began diffusing to other countries when British soldiers and settlers brought it with them to the various colonies of the empire, and today, most Commonwealth countries support active cricket cultures, though not all.

The case of Canada is particularly striking in this regard. Cricket was popular in Canada and the United States in the mid-nineteenth century - in fact, the first official international cricket match in the world took place between American and Canadian "elevens" in 1844 (Boller 1994a:23). The game's popularity rivaled that of baseball until the late nineteenth century, after which interest declined sharply. The game languished in both countries until quite recently, when new immigrants from the Caribbean and South Asia began arriving in North America in significant numbers (Gunaratnam 1993; Steen 1999). This pattern of adoption-then-rejection poses important substantive and theoretical issues regarding the cross-national diffusion of cultural practices. Given Canada's - and to a lesser degree, America's-demographic, cultural, and sociopolitical connections to Britain, the game's unexpected demise there is puzzling, especially in contrast to its successful diffusion in far less "British" parts of the Commonwealth. At the same time, this disjuncture also seems at odds with several important perspectives in the sociological study of diffusion.

\section{SITUATING CRICKET IN DIFFUSION THEORY}

There is widespread agreement that diffusion is the transmission, adoption, and eventual acculturation of an innovation by a recipient population (Coleman, Katz, and Menzel 1966; Rogers 1995; Wejnert 2002; cf. Palloni 2001). Most sociological studies of the diffusion process aim to identify the mechanisms by which an innovation spreads as well as the rate at which it does so in a given population.
Although there is now a rich body of important findings about this process, several major problems and gaps still exist.

One major failing of the diffusion literature is the tendency to overlook cases where innovations are transmitted but eventually rejected, as well as cases where adoption might have been expected but did not occur. Palloni (2001: 73-75) highlights two aspects of this problem in his important recent review of the field. First, he notes the common failure to try and account for the persistence of diffused practices in their new surroundings - how and why, in other words, do diffused practices become part of the lived experience of those who have adopted them? Second, he notes the obverse: that after the initial adoption of an innovation, mechanisms might arise that undermine its retention. Palloni (2001:73) adds that, "Despite the fact that this is a key part of a diffusion process, it is rarely mentioned and almost never explicitly modeled or studied." The problem, we suspect, is that many diffusion studies track cultural practices that are not commonly rejected, such as the adoption of new, time-tested medical or agricultural practices. Strang and Soule (1998: 268) observe, for example, that there is "a strong selection bias in diffusion research, where investigators choose ultimately popular [i.e., widely diffused] practices as appropriate candidates for study." Issues such as the persistence and rejection of diffused practices are thus generally overlooked in the literature.

Another shortcoming of diffusion studies is highlighted by Wejnert (2002:299-302), who notes a tendency in the literature to ignore the role of characteristics unique to the practice or thing being diffused. Specific features of the innovation being adopted, such as its potential for replication and change, play an important but often overlooked role in the ultimate success or failure of diffusion. By confining their studies to simple physical objects or cultural routines that are diffused at the micro-social level, diffusion scholars have tended to create advanced formal models that overlook real-world obstacles to diffusion - those posed by the nature, complexity, continuity, and potential mutability of the innovations themselves. Wejnert (2002) also notes the often overlooked distinction between innovations that are diffused at the macro- and micro-social levels. Those involving large collective actors such as countries and 
industries likely have different consequences and diffusion mechanisms than those that involve mainly individuals or firms.

The dominant "relational" approach to diffusion research in sociology has improved our knowledge of the role of social networks in the transmission of information and ideas (e.g. Buskens and Yamaguchi 1999), but it tends to underspecify the role of social structural factors such as class, status, and power in the adoption or rejection of innovations. In this light, Burt (1987), Marsden and Podolny (1990), and Van den Bulte and Lilien (2001) have revised Coleman, Katz, and Menzel's (1966) classic study of the adoption of a new antibiotic drug among a community of Midwestern doctors, but diffusion research has otherwise largely neglected these topics. It is significant, note Mizruchi and Fein (1999), that sociologists have widely overlooked the role of power in DiMaggio and Powell's (1983) celebrated study of the diffusion of organizational forms. Inequality, in particular, seems to be a neglected subject in the diffusion literature. Rogers (1995:7) makes a distinction between homophilous and heterophilous diffusion processes - that is, those in which the change agents and adopters either share or do not share comparable social positions-but fails to explore the ramifications of the latter situation in detail. As we will see in the case of cricket, status differences and the attendant mechanisms of distancing and inclusion can be decisive variables in explaining the adoption of cross-nationally diffused cultural practices. It will be shown that a top-down, or vertically heterophilous, process of diffusion best explains diffusionary success in some cases.

Some sociologists who work within the institutional framework of diffusion studies have, happily, attempted to address these concerns (see, e.g., Clemens and Cook 1999; Cole 1989; Dobbin and Sutton 1998; Guillén 1994; Lillrank 1995; Meyer and Hannan 1979; Molotch, Freudenberg, and Paulsen 2000; Patterson 1994; Strang 1990; Strang and Meyer, 1993; Starr 1989). While we applaud the temporal and causal acuity of these studies, we think there are further insights to be gained from case studies that explore the cultural and structural complexities of the diffusion process in broad sociohistorical terms.

The case study presented here will focus on a Western social practice that is, by any meas- ure, an internally complex cultural entity with powerful symbolic and political consequences (Appadurai 1996; Beckles and Stoddart 1995; Bourdieu 1978; Maguire 1999; Malcolm 2001; Miller et al. 2001; Nandy 2000; Patterson 1995; Stoddart 1988). It involves cross-national diffusion among large collective entities engaging broad arrays of both practitioners and spectators. It illustrates both the successful diffusion of a politically potent national cultural practice and the potential for such diffusion to be discontinued midstream. Finally, the case of cricket highlights the roles of social structure and "cultural power" in the diffusion process.

We first dispense with several common explanations of the diffusion of cricket, each of which hinges on one or another argument about national culture. Instead, we demonstrate the need to consider four aspects of the adopting countries' social systems that appear to mitigate the potential diffusion of a cultural practice from a "dominant" power to its "subordinates": social stratification, secondary education, entrepreneurship/network-building, and indexical nationalism, or the frame of reference in which citizens measure their own national accomplishments. Of the four, social stratification seems to have had the most widespread (i.e., generalizable) impact on the global diffusion of cricket, though this occurred at least partially through indirect effects related to the other three. Before explaining any of this in more detail, however, we will enumerate our study population, evaluate evidence relating to the popularity of cricket and other sports in various countries, and outline the criteria by which we measure national sports cultures.

\section{CRICKET'S UNIVERSE: THE STUDY POPULATION}

As noted earlier, our primary concern here is the transmission of a complex innovation between very complex collective units. ${ }^{1}$ This presents formidable problems of verification, made more

\footnotetext{
${ }^{1}$ Admittedly, one shortcoming of this particular case study is that it pertains primarily to male athletes and sports fans in the countries in question. Nonetheless, we have no reason to expect that our findings would be different were we to study a sport or other "national" cultural practice with greater cross-gender appeal.
} 
difficult by the fact that there are limited data sources on sports during our period of focusthe mid-nineteenth through early twentieth centuries. Were our objectives similar to those of most current sociological studies of diffusionestimating the rate and efficiency of diffusion given several different types of network structure - such data problems would be insurmountable. Our task, happily, is different and makes far fewer quantitative demands on the available historical data. We are concerned, instead, with uncovering those covariates that explain ultimately successful or unsuccessful cases of diffusion among the population of societies exposed to the game of cricket. It will thus be enough for us to define, first, the population of British-influenced societies that were exposed to and that initially played the game (the population of potential long-term adoptees); and second, the success or failure of adoption in each case within that population, including cases where discontinuation followed successful adoption. Please note that the focus of our inquiry is on the early period when cricket was first being institutionalized in England and spread throughout its colonies (i.e., the 19 th and early 20 th centuries). Much happened in the cricket world after World War II (when many of these colonies gained independence) that we cannot account for here. Wherever possible, we try to account for late-twentieth-century manifestations of the game, but our empirical focus is on the earlier period in which the game was either successfully or unsuccessfully transplanted to the various British settlements considered here.

One reason the global diffusion of cricket is of particular sociological interest is that it is so strongly associated with a specific country of origin. Cricket was first played in England, and since its earliest years, global diffusion of the game has been controlled by Englishmen and their cricket clubs. C.L.R. James (1963:164), the great West Indian social analyst, once wrote, for example, "Cricket was one of the most complete products of that previous age to which a man like Dickens always looked back with such nostalgia. ... It is the only contribution of the English educational system of the nineteenth century to the general education of Western civilization." Similarly, J. A. Mangan (1986: 153), author of The Games Ethic and Imperialism, wrote, "Cricket was the umbilical cord of Empire linking the mother country with her children."
Moreover, the game was deliberately "exported" to the British colonies as part of British colonial policy. According to one historian of the game, Brian Stoddart (1988: 658), "Cricket was considered the main vehicle for transferring the appropriate British moral code from the messengers of empire to the local populations."

International cricket has long since been dominated by ten core constituencies, each of which is officially recognized by the International Cricket Council (ICC) as "qualified to play official Test matches." The ICC was founded in England in 1909 and originally comprised just three member countries: England, Australia, and South Africa. (South Africa was expelled from the Commonwealth, and thus the ICC, in 1961 but was reappointed to the ICC as a "full member" nation in 1991.) In 1926, India, New Zealand, and a conglomeration of British Caribbean islands (the West Indies) were added to the ICC's membership, allowing them to compete in global competition at the highest level. The remaining four full-member nations are Bangladesh, Pakistan, Sri Lanka, and Zimbabwe. These ten countries thus make up what one might view as those parts of the world in which cricket has in fact attained the status of "hegemonic sports culture." Note the conspicuous absence of Canada, itself a major Commonwealth country. The United States is excluded as well. These twelve nations - the world's ten major cricketing countries plus the United States and Canada - constitute the primary set of cases analyzed here (see Table 1).

All of the foregoing reaffirms that the global diffusion of cricket is more than just a case of a popular sporting activity being adopted by societies around the world. Cricket has never been an Olympic sport, and its main international body, the ICC, was originally an appendage of the British colonial state. Until 1965 , in fact, it was the express policy of the ICC to admit only Commonwealth countries as members - the International Cricket Council was actually named the Imperial Cricket Council until 1965, further evidence of its distinct ties to the British colonial system. At the same time, it is rather ironic that so many countries with painful colonial histories-India and the West Indies, for example - dominate the sport today. We will explore in detail all of the questions raised so far, but first, we must out- 
Table 1. The Study Population in Brief

\begin{tabular}{|c|c|c|c|c|}
\hline $\begin{array}{l}\text { Potential Adopter } \\
\text { Nations }\end{array}$ & $\begin{array}{l}\text { Key Period of } \\
\text { "Popularization" }\end{array}$ & $\begin{array}{l}\text { "Successful" } \\
\text { Adopters }\end{array}$ & $\begin{array}{l}\text { "Failed" } \\
\text { Adopters }\end{array}$ & References \\
\hline Australia & $1850 \mathrm{~s}-70 \mathrm{~s}$ & $* * * *$ & \multirow{5}{*}{$* * * *$} & $\begin{array}{l}\text { Cashman 1998a; Mandle 1973; Pollard } \\
1987\end{array}$ \\
\hline $\begin{array}{l}\text { British Caribbean } \\
\text { (West Indies) }\end{array}$ & $1830 \mathrm{~s}-60 \mathrm{~s}$ & $* * * *$ & & $\begin{array}{l}\text { Beckles 1998a, 1998b; James 1963; } \\
\text { Stoddart 1998a; }\end{array}$ \\
\hline Canada & $1860 \mathrm{~s}-90 \mathrm{~s}$ & & & $\begin{array}{l}\text { Boller 1994b; Hall and McCulloch 1895; } \\
\text { Metcalfe } 1987\end{array}$ \\
\hline England & 17 th -18 th centuries & $* * * *$ & & $\begin{array}{l}\text { Allen 1990; Brookes 1978; Dunning and } \\
\text { Sheard 1979; Mandle 1973; Sandiford } \\
\text { 1998a }\end{array}$ \\
\hline $\begin{array}{l}\text { India (including } \\
\text { Bangladesh \& } \\
\text { Pakistan) }\end{array}$ & $1880 s-1900 s$ & $* * * *$ & & $\begin{array}{l}\text { Appadurai 1996; Bose 1990; Cashman } \\
\text { 1980, 1998b; Nandy } 2000\end{array}$ \\
\hline New Zealand & $1860 \mathrm{~s}-90 \mathrm{~s}$ & $* * * *$ & \multirow{5}{*}{$* * * *$} & Ryan 1998; Reese 1927 \\
\hline South Africa & $1860 \mathrm{~s}-80 \mathrm{~s}$ & $* * * *$ & & Merritt and Nauright 1998; Stoddart 1998b \\
\hline Sri Lanka & $1880 \mathrm{~s}-90 \mathrm{~s}$ & $* * * *$ & & Cashman 1998b; Perera 1998, 1999 \\
\hline United States & $1860 s-90 s$ & & & $\begin{array}{l}\text { Boller 1994b; Kirsch 1989, 1991; Mrozek } \\
\quad 1983\end{array}$ \\
\hline Zimbabwe & $1890 s-1900 s$ & $* * * *$ & & Stoddart 1998b; Winch 1983 \\
\hline
\end{tabular}

line more specifically how we determine "successful" diffusion.

\section{HEGEMONIC SPORTS CULTURE: DEFINITION AND APPLICATION}

By what criteria do we designate some countries as "cricket-playing countries" and others as merely countries where cricket is played, or not played at all? In trying to define what exactly constitutes a national sports culture we borrow Markovits and Hellerman's (2001) concept of "hegemonic sports culture." In their timely monograph, Offside: Soccer and American Exceptionalism, Markovits and Hellerman ask why soccer (i.e., "football" in international parlance) is not more popular in the United States. Americans play soccer, field an increasingly competitive World Cup squad, and have supported professional soccer leagues of varying success, but, argue Markovits and Hellerman, soccer is still not a national pastime in America. By this they mean that there is not a large audience for soccer among American sports fans. Soccer matches are not major events in America, players are not idolized, and the sport is not a common topic of conversation as are football, baseball, and basketball. In other words, a hegemonic sports culture is one that "dominates a country's emotional attachments" (Markovits and Hellerman 2001:10).
Nevertheless, measuring comparative levels of "emotional attachment" to sport is extremely difficult. Should emotional attachment be measured relative to those who are self-reported sports fans? Or should we more properly consider what percentage of the total population is committed to, or at least interested in, a given sport? There is no clear answer to this question, nor do Markovits and Hellerman attempt to provide one. They argue for a more qualitative, impressionistic approach: Are the local sports pages filled with soccer news? Do patrons at bars and cafes talk soccer with any frequency? Does one see soccer stars endorsing major products on TV and in print media? How is soccer represented in the media relative to other sports?

To give but two brief examples, we searched the sports pages of one major Canadian and one major Australian newspaper (both with free Internet editions) for the day July 17, 2002. The Sydney Morning Herald, a major daily newspaper from Sydney, Australia, contained an entire section devoted to cricket news (www.smh.com.au/sport/cricket). On this particular day, it included 10 articles on cricket, spanning the range from "Wanted: Australian all-rounder" (i.e., a player who can pitch, field, and bat equally well) to news of the birth of cricketeer Adam Hollioake's son. This is exactly the kind of minutiae that constitutes a hegemonic sports culture. Fans are interested not 


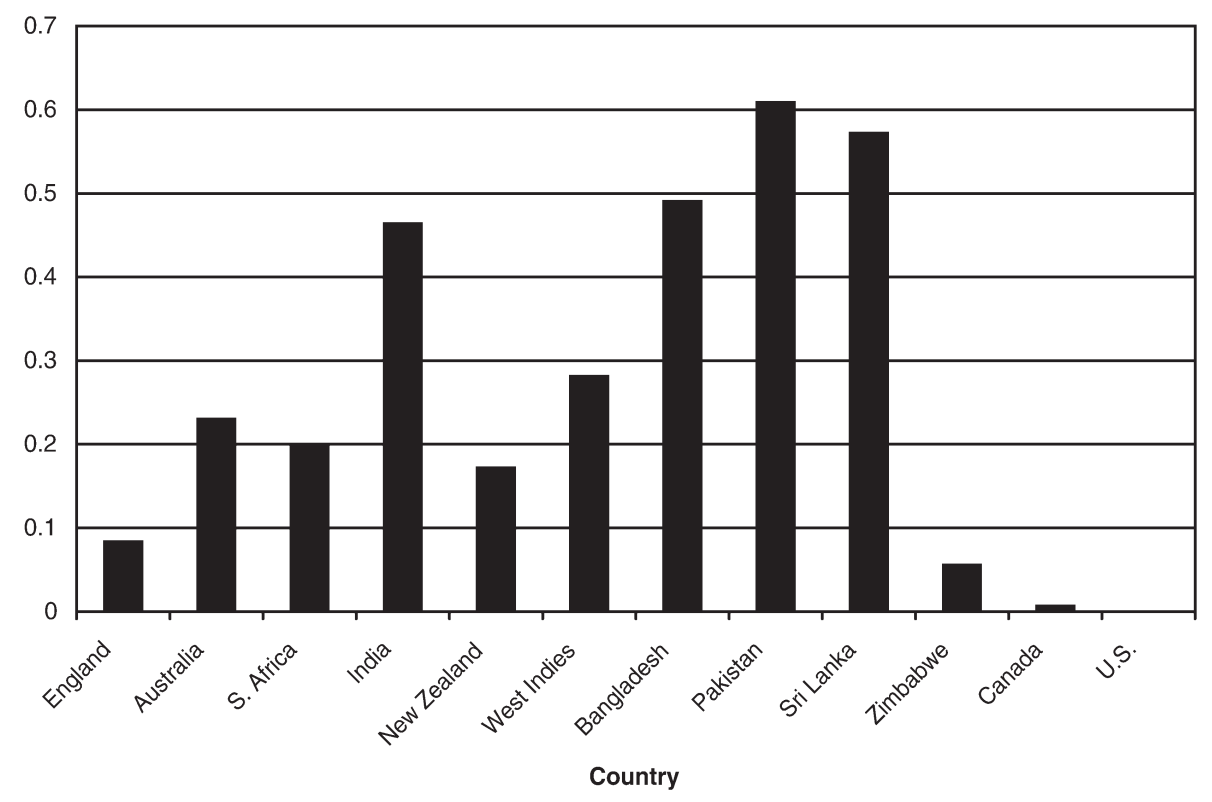

Figure 1. Average Percentage of Sports Stories about Cricket in Select National Newspapers

Note: Online editions: October 15, 2003; January 6, April 15, July 5, 2004

only in the latest standings and scores but in the future prospects of leading teams and even the daily ups and downs of players' lives. In contrast, the Toronto Globe and Mail (www.globeandmail.ca), one of Canada's leading daily newspapers, did not post a single article about cricket on this day at the height of the warm-weather season in Canada. If this is any testament to the local salience of cricket, Canadians regard it as a marginal practice indeed.

Figure 1 illustrates a more systematic comparison of cricket coverage in the sports pages of online newspapers from 12 relevant countries at four points in time (one day in each season of the year). ${ }^{2}$ Of the 12 articles surveyed, the United States, Canada, and Zimbabwe contained the fewest articles on cricket. Shortly, we will recount the history of cricket in the

\footnotetext{
${ }^{2}$ Actual newspapers searched were the Evening Standard (London, England - January) and the Times Online (London, England - October, April, and July); the Sydney Morning Herald (Sydney, Australia); the Mail and Guardian (Johannesburg, South Africa); the Times of India (Delhi, India); the New Zealand Herald (Auckland, NZ); the Jamaica Observer (Kingston, Jamaica); The Independent (Dhaka, Bangladesh); the News International (Islamabad, Pakistan); the
}

United States and Canada in detail. We do not attempt to deal with the case of contemporary Zimbabwe owing to the vast disruptions experienced in its political and economic systems of late. We suspect that expressing an interest in anything as "British" as cricket in contemporary Zimbabwe could in fact be quite dangerous. This was not the case in earlier decades, however, as evidenced by Zimbabwe's admission into the top tier of "test match" cricket. Note, too, that England has the next lowest number of cricket stories - an average of only about 8 percent of the sports coverage on these particular days, though 17 percent of the sports coverage was dedicated to cricket in the one "summer" edition we investigated. (There was no such summer "bounce" in the Canadian and American newspapers that we examined.) Naturally, these percentages reflect not only local interest in cricket but also the prevalence of newsworthy events in other local sports. Our concern here is not on the exact distribution of coverage, however, but on the popularity of cricket more generally. From what we found in

Daily News (Colombo, Sri Lanka); the Standard (Harare, Zimbabwe); the Globe and Mail (Toronto, Canada); and USA Today (United States). 
these newspapers, we can tentatively conclude that cricket has become a "hegemonic sports culture" in much but not all of the Commonwealth. Our endeavor is to explain this variance in the diffusion of the sport.

Nonetheless, because much of the variance on the dependent variable comes from the negative cases of Canada and the United States, it only seems fair to ask once again: Is cricket really that unpopular in these countries? For a better perspective on the popularity of the sport over time, we consulted electronic indices to two major newspapers: the New York Times for the United States and the Globe and Mail for Canada. ${ }^{3}$ Using a keyword search, we documented how many pages of newsprint included the word "cricket" each year. To provide a reference point for articles about cricket, we also did a comparable search for articles including the word "baseball." This allows us not only to track the relative popularity of the two sports but also to control for variance in the amount of newsprint devoted to general sports reporting in each newspaper over time. It is possible, if not likely, that at least some of the articles bearing reference to these words are not actually about the sports in question-American cricket clubs sometimes held tennis and golf tournaments on their grounds in the early twentieth century, for example - thus inflating somewhat the number of "hits" counted per year. We were unable to access and analyze every article bearing one of these two words, so we opted instead merely to count them all and discount discrepancies as random error. The data presented below is thus not perfect evidence of the changing popularity of cricket and baseball in the United States and Canada, but it at least offers a proxy measure of the prevalence of news coverage of the sport in two major national newspapers over time (see Figures 2 and 3 ).

As shown here, baseball and cricket were about equally represented in the Canadian sports pages until 1900 and generally kept apace until 1935, after which a large disparity appears in favor of baseball. The divergence is more obvi-

${ }^{3}$ The New York Times index is supplied by Chadwyck-Healey and available at http://historynews.chadwyck.com. The Globe and Mail index is supplied by Proquest and was accessed through a site license purchased by the National Library of Canada. ous in the American paper: the number of baseball references quickly begins outnumbering cricket references in the 1880s. Nevertheless, some readers might be surprised to learn that cricket had a significant following in the United States in the 1850s and 1860s. Some readers may also be surprised to learn that baseball is actually, and long has been, quite popular in Canada (Barney 1992). Not only did Canada host two major-league baseball teams (until 2005), but also baseball diamonds are a common sight in most Canadian suburbs (Barney 1989; Boller 1994b; Bouchier and Barney 1988). "The game has been played, in one form or another, throughout the country since the early 19th century," writes sport historian William Humber (1995:1). Though Canadian interest in baseball may well have peaked with the success of the Toronto Blue Jays in the late 1980 s and early 1990 s, it seems fair to say that baseball is significantly more popular in Canada than cricket.

\section{TRADITIONAL EXPLANATIONS OF THE FAILURE OF CRICKET IN CANADA AND THE UNITED STATES}

In trying to explain the virtual absence of popular interest in cricket in the US and Canada, we encountered several common arguments. The most obvious, having to do with climate, is tempting but ultimately unsatisfactory. True, Canadians are fanatical about ice hockey, a decidedly cold-weather sport; and true, most of the leading cricket-playing nations do not suffer particularly cold winters. On the other hand, Canadians enjoy a wide variety of warmweather sports, including not only baseball but also field hockey, football, and lacrosse. Furthermore, England, where the game was invented, is hardly a "warm" country itself. Indeed, the game is played there only in the summer season, which is subject to more rain than many parts of Canada. Nor has cricket survived in the more temperate parts of the United States or Canada. Weather, obviously, is not the answer.

Some historians of cricket in the United States have suggested that the sport is not more popular among Americans because it is inconsistent with their cultural worldview (Adelman 1986; Kirsch 1989, 1991). Cricket is a long, slow, tightly regimented game, they argue, whereas 


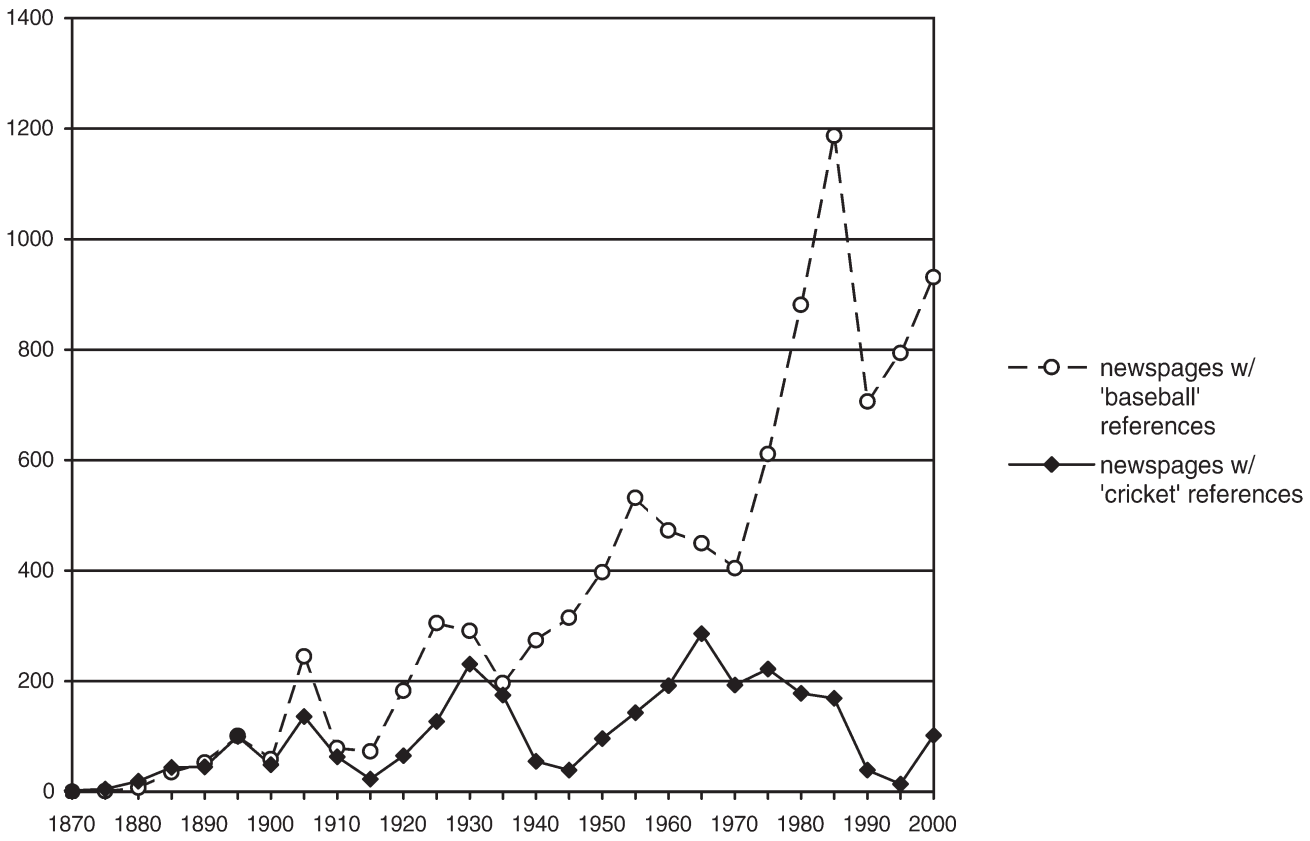

Figure 2. Canadian Sports Reporting: The Globe and Mail, 1870-2000
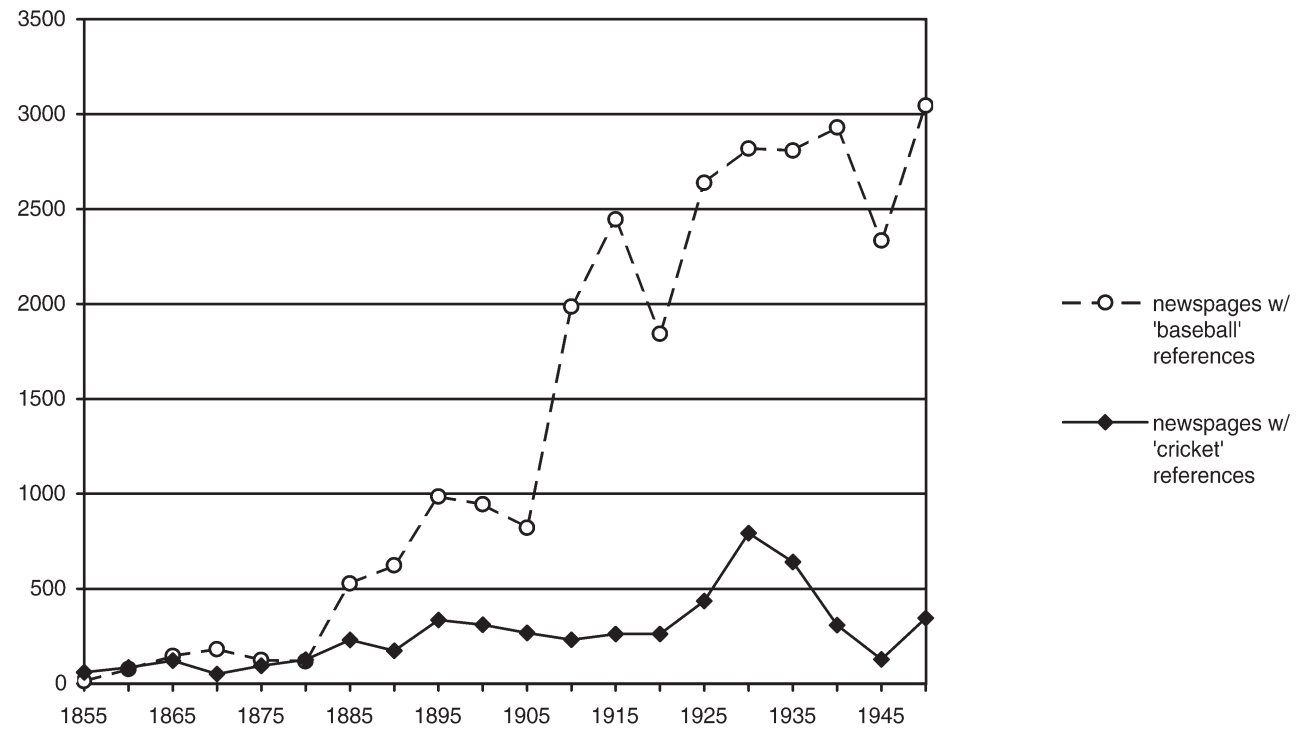

Figure 3. American Sports Reporting: The New York Times, 1850-1950

Americans are always in a hurry and anxious for results. According to nineteenth-century sportswriter Henry Chadwick (1868:52, quoted in Kirsch 1991:12), for example, "We fast people of America, call cricket slow and tedious; while the leisurely, take-your-time-my-boy people of
England think our game of baseball too fast. Each game, however, just suits the people of the two nations." True, cricket matches are generally longer than baseball games; nevertheless, time itself does not appear to be a sufficient explanation. While international test matches 
can last up to five days, many local matches are only one day in duration. In Australia, for example, an abbreviated "limited overs" version of cricket is popular with television audiences (Cashman 1998a). Anthropologist Arjun Appadurai (1996: 101) even argues that, "Cricket is perfectly suited for television, with its many pauses, its spatial concentration of action, and its extended format. ... It is the perfect television sport." Moreover, when played by amateurs, among whom wickets fall quickly, the game easily adapts to a spirited afternoon "knock" no longer than amateur soccer or baseball games. Note, too, that such perceptions are as much an effect of the differential status of sports as a cause thereof: Americans' pejorative descriptions of cricket are a product, as well as a cause of, the sport's wider failure to reach "hegemonic" status in the United States.

Similarly, cricket has been described by some as a sport that requires too much submission (i.e., orderly behavior) for Americans. Neither spitting nor swearing are officially condoned on the cricket field, for example, and disagreement with match officials is strictly forbidden. ${ }^{4}$

Nonetheless, while some might criticize Americans for their ungainly habits, this would hardly appear to constitute a satisfactory sociological explanation, particularly when Americans are so attracted to other sports that make similar demands of players, such as tennis and golf. And, even if this is true of Americans, it still leaves the question of Canadian habits unaccounted for. Given the frequency with which one hears Canadians described as modest, well-mannered, and community-minded people (e.g., Frye 1971; Lipset 1996), one would expect cricket to be wildly popular in the Dominion. In fact, a Canadian, James Naismith, invented basketball (in Massachusetts, USA) with these very characteristics in mind: "If men will not be gentlemanly in their play," he said in introducing the game to its first players (Wise 1989:124), "it is our place to encourage them to games that may be played by gentlemen in a manly way, and show them that science is superior to brute force with a disregard for the feelings of others." So

\footnotetext{
${ }^{4}$ We are told by an anonymous reviewer familiar with English cricket, however, that "county" cricket is rife with swearing and disputes with officials.
}

why didn't Dr. Naismith merely foist cricket on these "ungentlemanly" young Americans? Such explanations echo, in homely terms, the "cultural understanding" argument of diffusion scholars. We discount such explanations as overly simplistic and, in some cases, patently biased.

This brings us to another popular explanation of "Americo-Canadian Exceptionalism"Anglophobia. This perspective focuses on Canadians and Americans' (presumably negative) disposition toward England and the English. True, a significant minority of Canadians claim French, not English heritage, and a large percentage of Canada's Anglo-population also trace their heritage back to Scotland and Ireland - all possible reasons for Canadian antipathy toward a cultural practice as English as cricket. On the other hand, one can easily refute such arguments with reference to other cricket-playing countries: Australia was populated by many people of Scottish and Irish heritage, for example, and a large portion of its Anglo-population can actually blame the cruelties of the English penal system for sending their ancestors to Australia in the first place. The white population of South Africa, another cricketing nation, is also comprised of rival English and Dutch, as well as indigenous African, peoples. Why would Canadians be any more resistant to an English cultural practice like cricket than their counterparts in these other former colonies? Why, moreover, would Canadians be more hostile to English culture than the descendants of peoples cruelly subjugated by the English in places like Jamaica, Barbados, India, Bangladesh, Pakistan, and Sri Lanka? Finally, why would Americans be so enamored with tennis and golf, both sports with British origins, but not cricket? ${ }^{5}$ While we will argue that nationalism did play a significant role in American and Canadian attitudes toward cricket, we do not accept so facile an explanation as their contempt for all things British. Cricket

\footnotetext{
${ }^{5}$ It should be noted, moreover, that the popular North American sports of baseball and football have direct ties to the English games of "rounders" and rugby respectively (Dunning and Sheard 1979: 7). In the nineteenth century, two other British "public school" sports, rowing and track and field, were directly incorporated into American collegiate life as well (Smith 1988).
} 
was widely perceived by American and Canadian audiences to be a British "affectation" for reasons particular to the game's history in their respective countries. Explaining how this came to be is a major part of this project.

One related thesis about the decline of American and Canadian interest focuses on changes in the rate of English immigration to both countries (e.g., Metcalfe 1987). It is true that many early adherents of the game were British immigrants, civil servants, and military personnel, particularly in Canada, where British troops were garrisoned until 1867. In the United States, moreover, some cricket clubs, such as the famous St. George Club of New York, were largely peopled by British residents. Such ethno-national social clubs were exceedingly popular in the United States in the late nineteenth century (Kaufman 2002). Nonetheless, there is clear evidence that many "native-born" Americans and Canadians participated in cricket alongside their British-born counterparts in the late nineteenth century. Consider, for example, the following observation made in the 1895 book, Sixty Years of Canadian Cricket (Patteson quoted in Hall and McCulloch 1895:258): "The so-called American eleven in 1859 contained [only] one native-born American. ... In 1860 the number of Americans had slightly increased. And now, in 1894, all are native Americans 'bar one."' Furthermore, many of today's dominant cricketing countries have scarcely any population of direct British descent, and in the cases of Australia and New Zealand, one must still grapple with the question of how a British sport like cricket survived and flourished in the face of declining immigration flows and the declining influence of British culture and identity on their own national cultures. In other words, we must go beyond the question of cricket's transmission to the foregoing countries and ask how and why the sport was actually adopted by locals and reconstructed as a persistent national pastime (the final, acculturation phase of cultural diffusion).

One final "common" explanation of the failure of cricket in British North America is the rising popularity of baseball, an American sport with similar origins and style of play. There is some truth to this argument, at least to the extent that the rise of baseball and the decline of cricket do seem temporally related. Why this is so is hard to explain, however. Few Canadians would willingly admit that they prefer American to
British culture. In fact, a large part of Canadian national identity is focused around their very distaste for Americans and American cultural hegemony (Frye 1971). Why would Canadians replace English cricket with a sport from a country to which they are so poorly disposed? We take seriously the need to explain the rise of baseball and decline of cricket in two countries with distinctive cultural ties to cricket's motherland, England. We turn first, however, to the initial invention and diffusion of cricket in the British Empire.

\section{ANALYSIS-NETWORK-BUILDING AND CLASS COMPETITION IN THE GLOBAL DIFFUSION OF SPORT}

\section{THE INVENTION OF CRICKET \\ AND ITS ORIGINAL TRANSMISSION THROUGHOUT THE BRITISH EMPIRE}

Despite its stodgy reputation in America, cricket was not originally an aristocratic game. In its earliest incarnation cricket was, in fact, an agrarian pastime for modest farmers and craftsmen. Though historical precedents exist as far back as the twelfth century, English cricket is commonly thought to have come into its own in the seventeenth century (Allen 1990: 16-17; also Brookes 1978; James 1963:164). According to most historical accounts, it was gambling that truly inspired enthusiasm for cricket among England's upper classes (e.g., Allen 1990; James 1963; Sandiford 1994). Country gentlemen found that they could field highly competitive teams by hiring skilled "players" (i.e., professionals) to work on their estates, thus inaugurating a long tradition of collaboration between "gentlemen and players," in which elites and commoners played cricket side-by-side (Warner 1950).

At the same time, English elites encouraged their colonial subjects to play cricket because of the game's professed ability to discipline and civilize men, English and native alike. ${ }^{6}$ The literature on colonial cricket is rather explicit in

\footnotetext{
${ }^{6}$ Again, we regret the fact that women are not an especially relevant part of this case study. The question of English colonial attitudes toward the moral "improvement" of women is certainly a topic worth further consideration, though it is far beyond the purview of this particular study.
} 
this regard. After touring India and Burma with an amateur team from Oxford University, author Cecil Headlam (1903:168-69) commented, "[C]ricket unites, as in India, the rulers and the ruled. It also provides a moral training, an education in pluck, and nerve, and self-restraint, far more valuable to the character of the ordinary native than the mere learning by heart of a play of Shakespeare." Interestingly, Indian cricket was originally supported by British and Indian elites alike. Britons like Lord Harris, governor of Bombay from 1890-95, sponsored tournaments between Indian and English teams. Similarly, cricket-playing was endorsed and encouraged by local elites as "an aristocratic game which upheld traditional notions of social hierarchy and patronage" (Cashman 1979:197; also Bose 1990). Thus, it was a win-win situation for everyone concerned: cricket reaffirmed the authority of English and Indian elites over their respective constituencies while providing a forum for social interaction between them.

The same was true elsewhere in the colonies. Cricket was promoted as an English sport for both Englishmen and natives. In 1868, a famous all-Aborigine squad of Australian cricketers toured England. Parsi teams from India came in 1886 and 1888. Even in South Africa, nonwhites were encouraged to play cricket, though on rigidly segregated terms (Merrett and Nauright 1998:55-57). The British colonies in the Caribbean are particularly well known for their legacy of interracial play (Beckles 1998a, 1998b; Beckles and Stoddart 1995; Cozier 1978; James 1963; Sandiford 1998c). "From as early as the 1860 s the secondary schools and churches in Barbados deliberately began to use cricket as a socializing and civilizing agent," writes historian Keith Sandiford (1998c:1-2). "In those days the schools were dominated by headmasters who had come from Victorian Britain steeped in the public school ethos which then placed great store in team sports."

Indeed, the popularity of cricket in England itself owes much to its secondary education system. Cricket was regarded as an important right of passage for young British males, particularly those schooled in the elite "public schools" erected to train the future aristocrats of the empire (Mangan 1986; Penn 1999; Sandiford 1994; Stoddart and Sandiford 1998; Williams 2001).
[British] educators encouraged cricket participation among their students in the profound conviction that it produced better citizens as well as scholars.... [They] argued that organized sports could bring order and discipline to aggressive groups of rich, spoilt and rebellious brats... The public schools established the cricketing cult from about 1830 onwards. By 1860 it was an essential feature of their curriculum. (Sandiford 1998a:14)

So central did cricket become to British elite education that by the mid-nineteenth century, headmasters began hiring professional cricketers to coach their boys to victory over rival schools.

The creation of distinctly British secondary schools throughout the colonies of the British Empire also helped expose indigenous populations to the game. In Jamaica, for example, the educational system strongly promoted cricket in the secondary schools where, because of the merit principle in admissions, a substantial minority of darker lads of working-class background could be found. The same was true in the Asian Subcontinent, where promising young lads from low-status households were sometimes sent to English-style boarding schools and thus introduced to cricket. The importance of these schools in the cultivation of national cricket cultures is particularly evident in places where the educational system followed a different model. As Sandiford (1998b:4) points out, cricket languished in Anglo-African colonies like Kenya, Nigeria, and Uganda, where, in the nineteenth century, "European communities remained only minute fractions of the overall population and where the Victorian public school ethos never really took root." British-run secondary schools there were more committed to religious education than to competition and sport. This attitude was likely a result of the fact that British colonization began in these countries rather late, by which time the goals of imperialism had become somewhat more modest. ${ }^{7}$ The virtual absence of a dedicated white settler population contributed to a garrison mentality in which the English sought

\footnotetext{
${ }^{7}$ Note, however, that English colonial policy in places like India did not originally embrace the anglicanization of their native populations either-this was an innovation of the mid-nineteenth century in India (Cashman 1998b:118).
} 
to mollify, rather than civilize, their central African subjects. Similarly, the British did not encourage indigenous participation in cricket in the Far East (Stoddart 1998b:136-37).

Several unique features of the game itself appear to have facilitated its cross-national adoption and acculturation in many parts of the Commonwealth. That cricket requires no physical contact between players explains in part its diffusion to mixed-race and deeply class-divided colonies where "contact" sports like rugby and soccer/football were either ignored, practiced only among whites, or played along strictly segregated lines (meaning that white teams only played white teams, and so forth [Stoddart 1988]). Interracial play was permissible as long as it did not involve close contact, as with cricket. The formal attire of official cricket matches also helped smooth the way for integrated play - even in the searing heat of India and the Caribbean, players were expected to wear white or cream flannel trousers and longsleeved white shirts. It is significant, too, that even the most minor of games required two umpires dressed in authoritative white overcoats and that a cardinal principle of the game was that the umpires' decisions were always final. (The umpires were also invariably members of the elite class in interclass games.) These arrangements effectively curtailed any rabble-rousing or arguments that would demean the "masters" or undermine the pervasive atmosphere of noblesse oblige in the colonial milieu. Thus, even in England, nonwhites were permitted to play on local cricket teams. In fact, one of the most famous batsmen in all of English cricket history is a man known by the name of Ranjitsinhji, a native of India who originally learned the game at Rajkumar College and later played at the University of Cambridge before going on to become an English sports celebrity (Williams 2001:22-32).

Another important feature of the game that facilitated interracial play was "stacking," or "positional segregation," within teams. From its earliest period in Britain, we find stacking along class lines in cricket: bowling and wicket-keeping were performed by low-status "players" while the roles of star batsmen and captain were mainly reserved for high-status "gentlemen." The practice of stacking thus allowed elite Englishmen to recruit nonwhite and lower-class players without compromising the social segregation prevalent in English society more generally. Gentlemen and players were allocated separate changing rooms and entrances to the field of play; and separate accommodations were arranged for team travel; team captains were exclusively drawn from the amateur (i.e., high-status) ranks; and "professionals were expected, independently of relativities of age and skill, to call amateurs, 'Sir,' and, particularly when young, to perform menial duties around the ground" (Dunning and Sheard 1979:181). Stacking was even more important in multiracial British colonies, such as Jamaica, Barbados, and India, where "natives" were generally expected to specialize in bowling, thus leaving captaining, umpiring, and batting to their colonial overseers. Malcolm (2001) has shown that this pattern was not only transferred to the colonies but persists to this day in British cricket clubs where, as late as 1990, 70 percent of the bowlers were of West Indian and other colonial ancestry. Until fairly recently, even the most superlative nonwhite players were barred from captaining their clubs or national teams (Coakley 1998).

Nonetheless, enthusiasm for and participation in cricket became a national pastime in every former major colony of the British Empire except Canada and the United States. In the cricketing colonies, elite enthusiasm for the game was transferred to the population at large. In the United States and Canada, on the other hand, cricket remained largely a sport for country club members and elite boarding school students (Kirsch 1989, 1991; Lester 1951; Melville 1998; Metcalfe 1987; Redmond 1979). In other words, cricket culture had been transmitted to, and adopted by, some portion of the American and Canadian populations, but it failed to persist or develop as a popular pastime in both cases. Understanding variance in the global diffusion of cricket thus requires further investigation of the acculturation process, or the way the meaning and cultural significance of the game was transformed in the process of diffusion. As mentioned earlier, we do not find explanations based on "national values" or "cultural resonance" useful in this regard. Instead, we look carefully at the social systems of each country, as well as actual histories of the game (and related games) in them. 


\section{ADOPTION FOLLOWED BY FAILED ACCULTURATION: ELITE VERSUS POPULAR SPORTS IN CANADA AND THE UNITED STATES}

The most distinctive feature of the history of cricket in both the United States and Canada is its elevation to a pastime for elites only. In Canada, for example, cricket "gained a firm foothold among upper-class Canadians who were to perpetuate the game through the private schools. Cricket's longevity and persistence were directly related to its position within the highest levels of Canadian society" (Metcalfe 1987:8). Thus, one key to the rise and fall of Canadian cricket was the changing role of the game in Canada's elite universities and secondary schools. "Founded though they were by British public school alumni along British public school lines, the Canadian colleges refused to perpetuate the elitism of their prototypes or to preserve their outmoded curricula" (Sandiford 1994:148; also Dunae 1981). By the end of the nineteenth century, only the most elite boarding schools retained cricket, and even they began to encourage indigenous sports like hockey, lacrosse, and football in its stead (Mangan 1986:142-67). In the words of Donald King, Secretary to the Canadian Cricket Association (quoted in Sayen 1956:98), "[S]ome of our private schools play the game and feature it as part of their normal curriculum, but the private school here is in the minority and when the boys leave they often go and live in an area in which there is no cricket or perhaps the lure of golf or tennis proves stronger than enthusiasm for cricket when school days are over." Canadian boarding schools "kept alive the cult of athleticism," writes Sandiford (1994: 149), "but saw fit to promote a different brand of games. The behavior of the late-Victorian colleges in Canada differed markedly from that of their counterparts in [for example] India and the West Indies."

The Dismal FATE OF CRICKET IN CANADA. Translating these observations into sociological theory about diffusion failure requires some conjecture but is ultimately rather straightforward: As fewer Canadian elite schools devoted time to training young men in the finer points of cricket, the quantity and quality of play declined. Without fresh infusions of talent or widespread networks of league play, the game gradually took on the air of a marginal, old-fash- ioned pastime for antiquarians and Anglophiles. An 1895 account of Canadian cricket remarks, for example, that in Nova Scotia, "the same players were continually engaged in fighting out the same contests year after year, save only varied by the introducing of some fresh regiment or ship" (Wallace quoted in Hall and McCulloch 1895:124). "Cricket clubs of any size in Nova Scotia were few and far between," adds Wallace. "It needed, therefore, all the efforts of lovers of the game to keep up the necessary interest." Another 1895 commentator adds, "Only two or three comparatively small schools act as feeders to the ranks, always too rapidly depleted by the cares of life, by anno domini, and perchance, obesity" (Patteson quoted in Hall and McCulloch 1895:257-58). Sandiford (1994:148) concludes, "[D]uring the last quarter of the century, the game became associated more and more with an older and more oldfashioned Anglo-Saxon elite."

The central feature of the Canadian story is thus the isolation of cricket as a class-specific pastime. The clubby "Britishness" of Canadian elites may be one reason for this split, but the key causal factor remains the exclusivity of the sport, not its association with Britain per se. In looking at Canadian sports history of the late nineteenth and early twentieth centuries, one sees substantial evidence that cricket was an increasingly insular pastime, practiced only by those with the time and money to join exclusive clubs. Contributors to an 1895 volume, Sixty Years of Canadian Cricket (Hall and McCulloch, eds.), refer frequently to the gentlemanly, amateurish nature of the Canadian game, as compared to its quasi-professional English variant. In addition, Canadian sports historian Richard Gruneau (1983:108-9) notes that elite sports teams in Canada actually began avoiding competition with non-elite teams in the mid-to-late nineteenth century. Gruneau (1983:109) hypothesizes that "as the Canadian class structure began to elaborate, and as meritocratic liberal values began to develop widespread support, members of the dominant class apparently became unable to tolerate the possibility of defeat at the hands of those they considered to be their social inferiors. They also may have become progressively more alarmed at the prospect that commercialism in sport could very easily get out of hand under such conditions and vulgarize traditional upper-class 
views of "the nobility of play." Cricket had become for them something precious, part of their heritage, an elite pastime more akin to ancestor worship than play. In England, by contrast, cricket remained something spirited and boisterous, as well as highly competitive, thus facilitating the incorporation of low-status "players" into the game.

Counterfactual: THE RISE OF BASEBALL IN THE United STATES. This last observation points to a second facet of cricket's ultimate rejection in North America: its failure to cultivate mass appeal through frequent matches in which large crowds, intense rivalries, and spirited fans might bring the sport to the attention of major portions of the population. The history of American baseball provides a telling comparison with that of cricket in both the United States and Canada. Though baseball and cricket both began as relatively informal leisure games in the United States, baseball was later blessed by a cadre of brilliant entrepreneurs determined to make it the "nation's pastime." One such person was A. G. Spalding, star player, manager, league organizer, and sports manufacturer. To call Spalding an impresario or a marketing genius would be a bit of an understatement. He engaged in every part of the game, from promoting star players and intercity rivalries to squelching nascent efforts at labor organization among players (Levine 1985).

In addition to cricket, baseball had other rivals for people's time and money in the United States - crew regattas were major business for some time, for example, as were bicycle races, track meets, and college football games (Smith 1988). Spalding helped secure baseball's place in American national culture through a twopart strategy: On the one hand, he promoted the highest possible level of play with the widest possible audience by creating and managing a system of professional league play throughout North America. On the other hand, he built a manufacturing and marketing empire devoted to selling youngsters the accoutrements of the game - the Spalding name still stands prominent in the world of sporting goods. In the late 1870s, after a successful career as player and manager, Spalding published an official rulebook for the game and also licensed official merchandise for play. Spalding also produced bats and balls of different sizes and shapes for players of var- ious abilities and backgrounds. Noting that American educators were increasingly interested in finding healthy leisure pursuits for students, Spalding donated equipment and trophies to groups like the Public School Athletic League (Levine 1985:110-12). ${ }^{8}$ Spalding is even credited with inventing the now widely discredited "Cooperstown myth," by which the origins of baseball were explained in a compelling story of its humble but ingenious small-town roots (see Spalding [1911] 1992).

Note too that A. G. Spalding worked hard to curry the interest of elites, as well as the masses, in baseball. Upon returning from an 1889 "world tour" in which Spalding traveled with a hand-picked squad of professionals to Australia, Sri Lanka [then Ceylon], Egypt, Italy, France, and the British Isles, Spalding had his team greeted by a grand parade in New York City and then hosted a 300-person banquet attended by "Teddy Roosevelt, Mark Twain, local politicians, baseball officials, Yale undergraduates, and 'popular members of the New York Stock Exchange,"' among others (Levine 1985:107). Spalding's biographer, Peter Levine (1985:108) describes the tour's final, April 19th, stop in Chicago in terms worth repeating: "As the Chicago Tribune described it, 'the streets were thronged' with a crowd that 'represented all classes. Businessmen were in it, toughs and sports ... also a great many ladies. And they went fairly crazy." The parade was concluded "over expensive cigars and fine brandy at a reception attended by Chicago's elite...." Thus, Spalding made sure that the sport appealed to everyone, elites notwithstanding. He offered them a distinctive, exclusive niche from which to enjoy the game.

At the same time, Spalding contributed to the emerging American consensus that cricket was an effeminate game for men too precious to play baseball. In his best-selling 1911 book, America's National Game, Spalding boasts ([1911] 1992:7), "I have declared that Cricket is a genteel game. It is. Our British Cricketer, having finished his day's labor at noon, may don

\footnotetext{
${ }^{8}$ PSAL was founded in New York City in 1900 with the support of Andrew Carnegie, John D. Rockefeller, and J. Pierpont Morgan. It soon spread to other cities around the United States (Levine 1985: 110-12).
} 
his negligee shirt, his white trousers, his gorgeous hosiery and his canvas shoes, and sally forth to the field of sport, with his sweetheart on one arm and his Cricket bat under the other, knowing that he may engage in his national pastime without soiling his linen or neglecting his lady. ... Not so the American Ball Player. He may be a veritable Beau Brummel in social life. He may be the Swellest Swell of the Smart Set in Swelldom; but when he dons his Base Ball suit, he says good-bye to society, doffs his gentility, and becomes - just a Ball Player! $\mathrm{He}$ knows that his business now is to play ball, and that first of all he is expected to attend to business. ... Cricket is a gentle pastime. Base Ball is War! Cricket is an Athletic Sociable [sic], played and applauded in a conventional, decorous and English manner. Base Ball is an Athletic Turmoil, played and applauded in an unconventional, enthusiastic and American manner."

Naturally, Spalding was mischaracterizing the nature of English cricket, and English society more generally. The English aristocracy had long prided itself on the rough and tumble sports practiced at its most elite boarding schools. The relevant point is that Spalding, and many like him, were contributing to the development of a specifically North American perception of cricket. Indeed, this stereotype of elite British society likely attracted some American and Canadian men to the game-Canadian cricketers increasingly focused on cultivating a gentlemanly ideal of elegant, amateur play. As for the United States, an 1875 description of life at Harvard College (Vaille and Clark 1875:421) says the following of the Harvard Cricket Club, founded in 1862: "Though never very popular with the athletes of the College, it has always found supporters enough to keep it in a moderately vigorous existence." Thus, the emerging image of cricket as an ultra-elite pastime both repelled and attracted followers.

At the same time, however, many of the wealthy sons of American and Canadian society eschewed cricket for baseball, perhaps, in part, because of late-nineteenth-century rhetoric about the manliness of American culture. The 1875 Harvard Book does not include reference to a college baseball team, for example, but the 1887-88 Annual Report (Harvard College 1889: $29)$ proudly reports a gift of $\$ 25,000$ from $\mathrm{Mr}$. Henry Reginald Astor Carey to build appropri- ate facilities for "the Baseball Nine." In fact, beginning in the $1860 \mathrm{~s}$ and $70 \mathrm{~s}$, baseball became an intensely popular sport at the nation's most prestigious colleges. America's first recorded intercollegiate game took place in 1859 between Amherst and Williams. Bowdoin, Middlebury, Dartmouth, Brown, Trinity, Hamilton, Princeton, and Kenyon all had organized teams by 1862 . "By the end of the 1870 s, a group of eastern colleges, consisting of Amherst, Brown, Dartmouth, Harvard, Princeton, and Yale, were playing regular home and away series of games" (Smith 1988:59). College teams also regularly played professional teams, and play was extremely competitive; so much so that the colleges began offering "financial incentives" to especially talented players (Smith 1988:62-66).

The incipient professionalization of college athletics presented America's elite college presidents with something of a conundrum, another key to understanding the trajectories of cricket and baseball in the United States and Canada. Baseball's popularity grew through the result of excessive promotion, intense competition, and a do-anything-for-victory mentality among coaches and players. Aspiring athletes at America's elite colleges were clearly attracted by the glamour and notoriety of the game. (Posh summer jobs playing exhibition baseball at resort hotels and other financial "perks" for playing were probably also attractions.) At the same time, college masters and alumni objected strongly to this development; they preferred a sports ethic closer to Spalding's stereotype of English cricket-leisurely, good-natured, and safe. College presidents had previously tried to ban excessively violent sports to no availAmerican-style tackle football was first developed at Harvard College, where it was repeatedly and unsuccessfully banned by the president. American college presidents responded to the emergence of pay-for-play with equal reproach. Even the notion of hiring professional, full-time coaches for college teams was originally considered anathema by college boards (Mrozek 1983; Smith 1988; Townsend 1996).

American college masters eventually managed to minimize financial incentives for student-athletes, but the wider "professionalization" of certain sports continued nonetheless. Crew, football, baseball, and track and field attracted enormous audiences, particularly when rival schools, such as Harvard and Yale, had 
their annual meetings. Winning teams often received valuable cash prizes. Competition became increasingly defined around key dates and rivalries. Thanksgiving Day became a focal point of the college football season, for example, and competitive schools could bring in tens of thousands of dollars at the gate. Major crew regattas and track meets could also bring in crowds of 10,000 or more (Smith 1988:30-34). By this time, therefore, any college athlete still devoted to cricket would had to have asked himself why he was willing to forego the glory and gammon of the era's more popular sportsespecially baseball, which essentially requires the same skill-set as cricket.

Whereas football, crew, and track and field all remained more or less confined to the collegiate arena, baseball supported a number of professional leagues in addition to the college teams. An 1888 New York Times story ("The Game Was Stopped") reports a crowd of 40,000 spectators at a professional baseball game outside of Philadelphia; so many, in fact, that the game was "called" after a mob of unseated fans surged onto the field at the end of the first inning. Pro-am baseball games were also a common occurrence, which surely contributed to the sport's popularity on college campuses. American baseball, in sum, increasingly resembled English cricket: a sport in which elites and commoners shared a passion for the game, one in which gambling, professionalism, and a willingness to do anything to win were fundamental.

CRicket In the United States. The place of cricket in late-nineteenth-century American society could hardly be more different: Though cricket was originally popularized in the United States by working-class immigrants from the British Isles, it later became a sport practiced by only a select few Americans (Melville 1998: 16-17, 25). Note, moreover, that while the increasing popularity of baseball did present a formidable challenge to American cricket, the two games existed comfortably side-by-side throughout the $1850 \mathrm{~s}$ and $60 \mathrm{~s}$. It was not uncommon, in fact, for cricket and baseball teams to challenge one another to matches in their rival's sport (Melville 1998:67). In truth, it was American elites' exclusivist attitude toward cricket that led to the sport's decline among the population at large. As in Canada,
American cricket players increasingly retreated to small, elite clubs, and competition with rival "elevens" was quickly restricted to a small coterie of suitable teams (Kirsch 1989:221-22).

Over time, the sport's snooty image took a toll on the popularity of cricket among Americans at large, an image that elites sought to cultivate. In contrast to the robust English tradition of "gentlemen and players," American cricket clubs strictly forbade professionals from play, even if it meant bitter defeat at the hands of traveling English and Australian teams. Melville (1998: 77; also 120-22) notes that, "As the old-line [American] competitive cricket clubs went into decline, their roles were assumed by cricket organizations dedicated to providing an environment of more socially selective participation upon strictly amateur lines." A 1907 New York Times story ("Cricket") quips, "Once more the game of cricket has been shown to be a languishing exotic in New York." It noted, "A visiting team of Englishmen have worked their will upon the local cricketers. ... In the West, New York is supposed to be the seat and centre of Anglomania. But the West ought to be softened when it sees how very badly New York plays the Anglican national game. Cricketally [sic] speaking, Philadelphia is the Anglomaniacal town." Indeed, with the exception of a few New England college teams, cricket thrived only in Philadelphia by the end of the nineteenth century. As early as 1884 , a New York Times story ("Philadelphia Cricketers") joked, "Residents of American cities where cricket is not played, except by a few homesick Englishmen, assert that it is played in Philadelphia because cricket is the slowest of games and Philadelphia the slowest of cities."

Regardless of the Philadelphians' supposed motives, it is true that a handful of Philadelphiabased teams provided the bulk of American training and participation in the sport during the late nineteenth and early twentieth centuries. One finds little evidence, furthermore, that the Philadelphians were concerned about the overall decline of interest in American cricket; in fact, they appear to have encouraged it. They confined the game to prestigious country clubs like the Merion and Belmont Cricket Clubs, founded in 1865 and 1874 respectively. Sports historian George Kirsch (1991:15) sums up the Philadelphia scene, and the American milieu more generally, by saying, 
“The upper-class 'Proper Philadelphians' who patronized the sport after the Civil War did not wish to convert the masses. They preferred their leisurely game because they were amateur sportsmen who had plenty of time for recreation. They supported the English game until the early twentieth century, when tennis and golf became more popular amusements for the upper class. Elite Boston cricketers and working-class English immigrants also kept the game going into the 1900s. But by the eve of the First World War very few were still alive who could recall the days when cricket had a chance to become America's national pastime."

Approximately 120 cricket clubs are said to have existed in the Philadelphia area at one time or another, at least ten of which still exist today. One might hypothesize that cricket thrived there in part because of the nature of elite Philadelphian society in the late nineteenth century. Says E. Digby Baltzell, a sociologist who has studied the American elite in detail, "[T]he flowering of New England was the product of an aristocratic social structure led by men with deep roots in the governing class of the society, going back to the glacial age; Philadelphia's Golden Age, on the other hand, was the product of a heterogeneous and democratic social structure whose leadership elites came largely from elsewhere and from all classes within the city" (Baltzell [1979] 1996:54). By our thinking, then, social mobility in Philadelphia might have prompted its "old-money" elite to look for ways to segregate themselves from the city's nouveau riche and upwardly mobile populations. Boston Brahmins had no such cause for status anxiety, given their long-standing dominance of the city's cultural and urban affairs, though they did establish other forms of elite cultural institution in their midst (DiMaggio 1982). Nor were social mobility and status anxiety unique to Philadelphia at this time. Thus, we think that there is a more salient explanation of the Philadelphia-phenomenon in American cricket, one that mirrors the success of American baseball at the national level.

Cricket seems to have survived in Philadelphia primarily because there was a critical mass of clubs ready to field competitive teams. Thus, though comparable numbers of elite men in other cities may have been interested in cricket, they failed to build (elite) cricket leagues that would sustain (elite) interest in the game over time. Put in more formal terms, the Philadelphians created a network "dense" enough to sustain a local cricket culture; they stayed above the "threshold" at which interest in collective pursuits risks extinction (Granovetter and Soong 1983). Haverford College, the University of Pennsylvania, and Princeton University dominated the late-nineteenth-century game largely because of their proximity to the "cricket nurseries" of Philadelphia (Lester 1951), and the former remains a central hub of American cricket to this day-Haverford not only pays a professional cricketer to instruct its current "elevens" but also maintains a special library collection devoted to the history of the sport. ${ }^{9}$ Elsewhere in the country (and in Canada), elite clubs failed to create viable leagues and thus faltered. The absence of a strong cricket culture in the notably stratified American South also makes sense in light of this explanation. The rural focus of late-nineteenthcentury Southern elites seems to have predisposed them against team sports of any kind. Southern leisure activities were generally more grounded in agrarian pastimes like hunting, fishing, and riding. Only much later, following the rise of large state universities in the South, did team sports like football, basketball, and baseball become mainstays of sporting culture for Southern elites and non-elites alike.

Nonetheless, even with the exception of Philadelphia, it would appear that the popularity of cricket in both the United States and Canada suffered primarily from the exclusionism of its elite practitioners. North American cricket prevailed, though weakly, in places where status anxiety was high among wealthy families and where these families established and maintained multiple dense networks of rival cricket clubs. In both Canada and the United States, an egalitarian ethos encouraged economic elites to cultivate exclusive status-based activities with which to maintain their superior position in the social system. Cricket was not an inevitable response to this status anxiety, but it was one viable option.

\footnotetext{
${ }^{9}$ The C. C. Morris Cricket Library at Haverford College is an especially useful repository of information about the past and present of American cricket. Online information, including a historical map of Philadelphia cricket clubs, can be found at http://www.haverford.edu/library/cricket.
} 
At the same time, however, even elite tastes began changing in the early twentieth century. Increasingly, America's wealthiest families "placed maximum importance on the pleasuring of the individual sportsman taken as a consumer, albeit a wealthy one, and on gratification as a suitable goal in his life" (Mrozek 1983: 106). Country clubs, though still popular, increasingly built their reputations on the quality of their clubhouses, tennis tournaments, and golf courses. According to the sporting news of the day, even long-standing cricket clubs began hosting tennis and golf tournaments on their grounds. Cricket was languishing.

The obvious irony here is that elitism spelled the death of a once-popular pastime in two countries known for their exceptional egalitarianism. Thus we ask: Why would elites in other countries not have done the same? How did cricket become so popular in these societies? Answering these questions requires that we look back at the cases in which cricket was successfully adopted and espoused by wide segments of the population, places like Australia, New Zealand, India, South Africa, and the West Indies. Despite their vast social and political differences, what do all these countries have in common beside their British colonial roots?

\section{ADOPTION AND SUCCESSFUL ACCULTURATION: CRICKET ELSEWHERE IN THE COMMONWEALTH}

It would appear that, in part, it was the very lack of a rigid social system that encouraged elitist attitudes toward cricket in the United States and Canada. Cricket became a marker of high social status, and the game was thus not promoted among the population at large. Conversely, rigid social stratification systems in other British colonial societies appear to have nurtured segregated but inclusive cricket cultures. In India, for example, love for the game was spread through the organization of matches between rival ethno-religious groups, each of which welcomed talented players from within their communities regardless of rank (Bose 1990). C. L. R. James's autobiographical accounts of Trinidadian cricket culture support similar conclusions. In Trinidad, as in Jamaica and Barbados, blacks and whites sometimes played cricket together (though not as equals). Individual cricket clubs were established at each rung of the social hierarchy, from the lowest- caste blacks to lighter skinned "browns" and whites. "I haven't the slightest doubt that the clash of race, caste and class did not retard but stimulated West Indian cricket," writes James (1963:72). Thus we see that the specific criteria of social stratification are less important than the existence of a cohesive vertical hierarchy in the receiver nation. Racial, socioeconomic, and/or ethno-religious differences could provide the basis of stratification with the same result: elites' decision either to actively promote or at least passively to permit the acculturation of cricket among lower social strata.

There are three mechanisms underlying this process in the case of cricket: First, colonial elites, comfortable in their place atop the social hierarchy, had little reason to discourage those beneath them from playing a game that paid symbolic homage to British cultural and political hegemony; in fact, elites tended to regard cricket as a good means of "civilizing" natives in their own image. Given a rigid social system, furthermore, emulation of those at the top had benefits for those at the upper-middle and lowermiddle rungs, particularly among nonwhites seeking "entry" into a white-dominant world. With opportunities for upward mobility so severely limited, moreover, cricket provided those of the lower castes some means of symbolic competence - that is, by competing against those of other castes, races, and classes, lowcaste cricketers could assert themselves in ways not permitted in ordinary society (Malcolm 2001).

Thus cricket was attractive to all major strata in these colonial societies. Even in Australia and New Zealand, where class mobility was relatively more common, yearning for status in the eyes of England created opportunities for "liberation cricket." Having been settled largely by working-class British immigrants, many of them "transported" to Australia as criminals, the Antipodes have long had a sense of cultural inferiority to England. British culture thus had an elevated status for Australians and New Zealanders of all classes. Understanding the Australian and New Zealand cases nonetheless requires a bit of extra background information, to which we now turn.

Australia And New Zealand. Though contemporary Australia and New Zealand are egalitarian, socially mobile societies much like the 
United States and Canada, matters were significantly different in the nineteenth century, the key years in the global diffusion of cricket. Socioeconomically, early Australian society was stratified into three classes: an upper-crust of absentee (mostly English) landlords; a middle class of émigré soldiers, artisans, and professionals; and a lower class of emancipated prisoners, their offspring, and the vast hordes of freemen tending sheep and sharecropping on other people's land (Clark 1995; Hughes 1986; Stone and Garden 1978). The key point about late-nineteenth-century Australia for our concerns is that its wealthiest citizens did not attempt to build strong institutional barriers between themselves and the rest of society. This may be the result of the elite's relative sense of security atop the Australian status hierarchy, though we suspect that it stems more directly from the fact that Australia was still a relatively new settlement at the time. Its richest citizens had yet to accumulate wealth or exclusive social networks comparable to those in the eastern United States and Canada. The separate classes desperately needed one another in the struggle to settle this vast, isolated continent. In the continent's burgeoning cities, for example, where Australian cricket truly thrived, the mercantile elite actively embraced the working classes, both socially and politically (Connell and Irving 1980). The presence of many British military men, moreover, coupled with the colony's distance from England, made English pastimes particularly valuable to Australians, particularly those activities that did not require fancy concert halls or awareness of the latest fads and fashions. Thus, Australia's various social strata cooperated in a nationwide effort to cultivate British ideals and social practices, cricket foremost among them (Clark 1995; Hughes 1986). The Sydney Gazette, according to one account (Pollard 1987:10), stated in 1832 that "cricket was now the prevailing amusement of the colony and that no gentleman could expect to 'dangle at a lady's apron strings' unless he could boast of his cricket prowess."

Nonetheless, urban elites did establish some fairly exclusive cricket clubs in Australia - the Melbourne Cricket Club was founded in 1838 on such grounds, thus prompting the formation in 1839 of a rival middle-class club, the Melbourne Union Cricket Club (Pollard 1987:
40-42). In this way, Australian cricket resembled the stratified game in other British colonies, such as India and the Caribbean. The key to the widespread popularity of cricket in Australia was, again, the decision of its wealthiest citizens to "share" the game with those of lower strata. Competitiveness trumped exclusivity in the minds of Australia's socioeconomic elite, in other words, much as it had done in eighteenth-century England. Having issued a challenge of one thousand pounds to any team in Australia that could beat it, the prestigious Melbourne Cricket Club signed a contract with a professional English cricketer to bolster its competitiveness with rival clubs. The MCC also hired a groundskeeper to eject nonmembers from club grounds. Both practices resembled the English cricket tradition in full flower-assiduously maintaining statusgroup distinctions while facilitating whatever integration was necessary to maintain the highest possible level of play (Pollard 1987:46-47; Dunning and Sheard 1979:181). This competitiveness also helped cultivate large audiences for the game: Match organizers for the MCC insisted that "spectators would not attend cricket unless the best players were on view." (Pollard 1987:143). They were clearly interested in popularizing the game among the widest possible audience. In only a few instances, such as distant Tasmania (originally known as Van Dieman's Land), did anything like the American and Canadian elites-only attitude manifest itself. Pollard (1987: 37) refers, tellingly, to the fact that Tasmanian cricket did not thrive owing to "the strange reluctance of the strong, prestigious clubs in Hobart and Launceston to hire professional players to coach and strengthen their teams."

Over time, Australian cricket remained a national pastime despite the democratization of its social, political, and economic systems. In the late nineteenth century, teams were often stratified by class and ethnic background, while a spirit of inclusive competition prevailed nonetheless (Cashman 1984). The widespread role of publicans in promoting Australian cricket personifies its popular nature: "[P]ublicans quickly realised that the promotion of cricket stimulated their business," notes one historian (Pollard 1987:10). Creation of neighborhood and trade-based cricket clubs was, moreover, a source of tremendous pride for urban boosters 
in cities like Sydney and Melbourne (Cashman 1998a; Pollard 1987). Sydney, in particular, struggled to distance itself from its origins as an English penal colony. Excellence at cricket appeared early on as a way for locals to make a statement about "the character of colonial society and the nature of the imperial relationship." "Thrashing the mother-land" was an indirect expression of "the love-hate relationship of a youthful colonial society attempting to define its identity and a greater sense of nationhood" (Cashman 1998a:36, 39; see also Mandle 1973:525-26). Hence, a long Australo-English rivalry began early on, and it is still a source of tremendous interest to Australian sports fans, particularly given their long-standing dominance over increasingly weak English teams. More important still is the fact that intra- and inter-provincial leagues were actively promoted early on in Australia, thus stimulating the creation of adequate playing grounds and competitive teams throughout the country. ${ }^{10}$

Cricket evolved along similar lines in New Zealand. Though New Zealand was never home to any English penal colonies, its wealthier citizens shared with those of Australia the sense that they needed to prove themselves in the eyes of the British. New Zealand cricket has its longest and strongest legacy of play in the province of Canterbury, "the most English of New Zealand provinces" and one founded upon economic principles designed to perpetuate the rigid social order of the English countryside (minus the truly poor). Here, class stratification and inclusive Anglophilia promoted cricket as a healthy pastime for all, excepting the native Maoris (Ryan 1998). ${ }^{11}$ Christchurch was home to both exclusive and "open" clubs. Elite schools began early on to train young men in the game, and the hiring of professional coaches from England was also common beginning in the 1890s (Reese 1927:41, 49). A steady stream of

${ }^{10}$ Interestingly, rugby was first promoted in Australia as a way for local cricketers to keep in shape over the winter months (Hickie 1993).

${ }^{11}$ It is not clear to us why white New Zealanders did not work to promote the game among Maoris in the same way that Australians did among the Aborigines. It may be related to the Maoris' fierce resistance to white settlement in the early years of the colony, but we were not able to confirm this.
English and Australian immigrants provided ready instruction and talent. Interprovincial play was also quite popular - when an annual match was first arranged between the neighboring provinces of Canterbury and Otago, "it was agreed that the teams should wear the great English university colours," Canterbury in Oxford's dark blue, Otago in the light blue of Cambridge (Reese 1927:36). The creation of several annual prizes - the Plunket Shield for best "major" team (generally those from major cities) and the Hawke Cup for best "minor association," as well as the Heathcote Williams Shield for best secondary school team-helped create the kinds of well-anticipated sports rivalries vital to the creation of a "hegemonic sports culture."

Promotion of the game in minor population centers through the Hawke Cup competition was clearly important to the long-term survival of the game in New Zealand. Emphasis among New Zealand cricketers was not on the social status generated by membership in elite clubs but on the prestige gained by winning. This was so much the case that a visiting Australian star, Warwick Armstrong, reportedly advised that the "various [Kiwi] associations are too inclined to pick the coach who can help his province to win matches. What is really wanted is the coach who can impart knowledge and keenness to the boy" (quoted in Reese 1927:76). In sum, New Zealand, like Australia, followed a somewhat different path to "hegemonic" cricket than British colonies in which a minority white elite dominated a majority colored population. Cricket helped Antipodean elites cultivate their Englishness, but the size and isolation of their European settlements limited the extent to which they could be truly exclusive. Everyone involved in the game aspired to gentility but none was excluded on the grounds of wealth or social standing. "Proper conduct, rather more than heredity, was the mark of an amateur gentleman," comments one history of Australian cricket (Pollard 1987:65).

The Asian subcontinent. Interestingly, it was not originally the intent of the British to popularize cricket in the subcontinent of Asia. British soldiers are said to have played the game in India as early as 1721, but it was not until the mid-nineteenth century that Indians actually began to play. Then, too, it was primarily the 
"middle-man" Parsi population that first cultivated the game. The Parsis were an ancient immigrant community in India known for their wealth and success at business. "It was no accident that the first community [in India] to take up the game were the Parsis," comments one historian (Cashman 1979:190-91). They were "a wealthy entrepreneurial group who acted as cultural brokers between the British and Indian society. ... In the tradition of colonial elites, the Parsis took up the game of cricket, along with other imperial customs, partly to demonstrate their fitness for the role of collaboration." Parsi success at the game also prompted India's elite Hindu and Muslim populations to take an active interest in it (Bose 1990:32).

From the start, indigenous participation in Indian cricket was centered around elites: Princes would build ornate cricket grounds and invite guests to watch them play. The princes would rarely even bowl or field the ball, relying on hired players to provide them easily hit balls. This provided valuable opportunities for Indians of lower social strata to get involved in the game. Audiences, too, were carefully segregated; Europeans from Indians, commoners from elite, men from women, and so on (Cashman 1998b:126-67; Cashman 1980). "So cricket prospered," comments Bose (1990:36), "not because the different communities mixed but because they did not. Competition, not cooperation, was the spur." Thus, elite members of India's vastly segregated social system embraced the game as a way of distinguishing themselves vis-à-vis the British and one another. Important for our purposes is the fact that talented nonelites were encouraged to play the game. The relative security of elites within their own communities, as well as their competitiveness with elites in rival ethno-religious communities, allowed for this kind of segregated-integration.

"By the 1930s," writes Cashman (1998b: 123), "there were many cricketing princes, players and patrons, who lavished great sums of money and energy to secure the top prizes in cricket, control of the game and captaincy of the side. ... Cricket prominence provided the princes with more clout in the Chamber of Princes and enhanced their status with the British." Rivalry between Indian and English sides developed from this, which subsequently helped cultivate further talent and interest among the public at large (Appadurai 1996; Bose 1990). The widespread incorporation of Indians into the British civil service system in India also exposed many indigenous men to the game. By 1947, when India became independent, cricket was a national passion, if not yet the national passion. Jawaharlal Nehru, first prime minister of India, further encouraged participation in the sport, himself having been educated at Harrow in England. In Bombay, where cricket has, perhaps, its longest history on the subcontinent, and where the Indian television and film industries are centered, star cricketers are given all the adulation and fame of their Bollywood counterparts (Cashman 1998b:130). Televised matches in indigenous languages have also helped build and maintain a wide fan base, as has the transference of regional political tensions onto the wicket - international test matches between India, Pakistan, Bangladesh, and Sri Lanka are, today, rabidly nationalistic events replete with hooliganism, jingoism, and sometimes outright violence (Appardurai 1996; Nandy 2000).

The West InDIES. The historic status hierarchies that nurtured passion for cricket in Indian society have a close parallel in the West Indies, where the game is equally popular today. Though originally cultivated by and for white elites in the British Caribbean, high-status blacks and Indians were provided some training in the game early on, thus leading to the eventual formation of cricket clubs for nonwhites. Clubs were rigidly stratified on color and class lines. Nonetheless, the status hierarchy was sufficiently rigid that space could be created for interaction and competition among them-just so long as it remained on the field. Beating a team from an adjacent status position was a feat worthy of respect, and though it did not ultimately change the social order, it did at least provide an outlet for status emulation and achievement. The possibility of being recruited to play professionally in England was further incentive for talented athletes from poor families to devote time and energy to the game. Because the symbolic stakes were high, moreover, large audiences would often turn out to watch and successful players would receive great acclaim. "Supporters of the respective sides had invested considerable amounts of emotional capital in the outcome," notes 
Stoddart (1998a:84), a development that later extended to international matches with sometimes violent consequences (Patterson 1995).

Thus we see another case where the relative stability of the status hierarchy within a society promoted a segregated but inclusive cricketing culture, one that gained valuable momentum from the muted tension of competition among status groups. Unique to the West Indies is the nature of their international "test" match status: rather than play as separate national teams, the "Windies" have traditionally comprised top players from throughout the Caribbean. The contemporary game in the Caribbean is thus less oriented around national pride than around racial and ethno-Caribbean solidarity (Beckles 1998b).

SOUTHERn AfRICA. The case of South African and Zimbabwean cricket is a bit more complicated and follows lines distinct from, though comparable to, those already described. The large presence of British military personnel provided a ready pool of talent for the game in southern Africa, but its diffusion to indigenous and Afrikaner populations was somewhat erratic. Some Afrikaners openly played cricket before the onset of the Boer War, and they gladly joined the British in a white unity movement during the Apartheid era, but the early twentieth century was a less active period for Afrikaner cricketers in the aftermath of the war. British whites, meanwhile, staked the very reputation of their settlements on the game. The small size of the Anglo-white population in South Africa meant that class distinctions among them were muted; cricket became a focal point of colonial life. Indeed, British South Africans and Rhodesians were in some ways more "British" than the British (Winch 1983). In colonial Rhodesia, for example, one memoirist noted, "Where previously one had to be a member of the la-di-da class to get a job in the Civil Service, now you had to beat the hide off a ball," meaning that prowess at cricket was sufficient means of attaining status and respect in the British community (G. H. Tanser quoted in Winch 1983).

Vitally important to the long-term success of cricket in southern Africa is the fact that the British allowed nonwhites to play the game there. Before the early 1900 s, when government-sponsored race policies began their long descent toward apartheid, British settlers actu- ally encouraged segregated play among middleclass blacks and Asians. "Because the ideology of respectability was crucial for the aspirations of middle-class blacks," they not only aspired to play the game well but also provided an example for less "respectable" blacks (Stoddart 1998b:56). Again, the relative stability of the status hierarchy in these societies allowed for the diffusion of the game from the top-down. Blacks were excluded from white cricket clubs, as well as the national teams, but they learned to play and to watch the game nonetheless. In the ensuing years, politics have been the greatest barrier to "hegemonic" cricket in South Africa and Zimbabwe. Opposition to apartheid limited South African participation in international test matches for a good part of the twentieth century, and the political turmoil in contemporary Zimbabwe may mean the permanent demise of cricket there.

Though the particulars motivating cricket adoption thus varied from one British colony to another, the development and perpetuation of a hegemonic cricket culture required in each case that members of high-status groups remained interested not only in cultivating their own cricket skills but also in sharing the game with those of lower orders. This did not occur in the United States or Canada.

\section{DISCUSSION}

\section{CRICKET AND SOCIOLOGICAL MODELS OF CULTURAL DIFFUSION}

Our analysis suggests an important extension of current diffusion theory. It is widely accepted among scholars in the field that diffusion is most likely to succeed where change agents and adoptees share the same culture and social category (especially the same socioeconomic status). Thus Rogers (1995:7) asserts as "an obvious principle of human communication that the transfer of ideas occurs most frequently between two individuals who are similar or homopholous," this being "the degree to which two or more individuals who interact are similar in certain attributes such as beliefs, education, social class, and the like. ..." Rogers contrasts this with situations where relations are heterophilous (i.e., the social position of the change agent is different from that of the adopters) and notes that this can present a major obstacle to successful diffusion. The ideal sit- 
uation in the initial adoption phase, he argues, is thus one in which change agents and potential adopters "would be homophilous on all other variables (education and social status, for example) even though they are heterophilous regarding the innovation" (Rogers 1995, 7; for similar views see Strang and Meyer 1993; Wejnert 2002).

We are inclined to agree that homophilous diffusion is indeed true in many, perhaps most, cases, especially those involving the intra-societal transfer of simple innovations among individuals. Our study, however, indicates that there is an important class of diffusion processes in which just the opposite might occur-i.e., cases in which a distinctly heterophilous relationship between change agents and would-be changeadopters promotes diffusion. In the case of cricket, it is precisely the stable status-inequality between those who brought the game from England and the lower-status colonial populations that adopted it that accounts for the successful diffusion of cricket. In such cases (i.e., top-down, or heterophilous, diffusion), it is the authority and high social status of change agents, combined with their willingness not simply to transmit but actively to participate in the promotion of the innovation, and their desire to continue their engagement with it even after it has begun to spread down and across the social hierarchy, that accounts for successful diffusion.

As shown in the case of cricket, all three elements are necessary for this kind of top-down diffusion to work: It is not enough for elites simply to introduce the innovation; they are required to promote it actively and to persist in lending it their prestige by continuing to practice it themselves. Where they do not, one of two outcomes, both fatal for the long-term acculturation of the innovation, is likely: One possibility is that the innovation becomes a fad, thereby enjoying a brief period of widespread popularity because of its upper-class origins, but later being abandoned by the elite transmitters because of this very popularity, thereby triggering a decline in overall popularity. The history of fashion is replete with examples of this (e.g., Crane 2000). Another possible "negative" outcome is that status-insecure first-adopters "capture" the innovation, thus preventing its diffusion into the population at large. Precisely this happened to cricket in Canada and the United States, as we have seen.

Naturally, the nature of social stratification in these Commonwealth countries is not sufficient to explain the success or failure of cricket in each country; nor does it fully explain the failed cases of Canada and the United States. Our earlier discussion of the rising popularity of baseball in the United States offers several keys to refining our explanation. Baseball was aggressively promoted throughout the United States by league-owners, sporting goods manufacturers, and "star" players. Inter-urban play helped promote widespread audiences. Youths were encouraged to play in and out of school, and the necessary equipment and playing grounds were made widely available. Similar efforts were made for football and basketball in the United States, and for cricket throughout much of the Commonwealth. Cross-class participation in such sports was supplemented, in other words, by intense efforts to recruit spectators, as well as new talent, to the games. At some point, such self-promotion seems to cross a threshold at which the game's popularity fuels itself: baseball was so popular and baseball rivalries so intense that even American elites flocked to it, thus leaving cricket virtually no following whatsoever. Absent celebrity players and careful marketing, crew and track and field, in contrast, lost momentum and popularity among American audiences.

The lessons here are rather simple: On the supply side, would-be audiences must be offered a steady stream of well-publicized events between evenly matched, talented teams. Annual matches, such as Thanksgiving Day college football games or "The Ashes," a biennial cricket match between England and Australia, help solidify a sport's place in the public mind (cf. Schudson 1989). On the demand side, a surfeit of opportunities whereby talented athletes can find selective incentives to devote time and effort to one sport over another also appears to make a difference. Such factors, it should be noted, can also erode support for a sport even after it has been successfully adopted. The popularity of professional rugby in the Antipodes, for example, and the spread of basketball to the Caribbean, both potentially represent threats to their nations' hegemonic cricket cultures.

The evolution of the game in each country, then, is the result not only of the relative status 
position of interested parties but also such intangibles as the rise of sports entrepreneurs devoted to the promotion of a specific sport; the rise of competitive league play, which helps draw regular 'fans' from different strata of society; and the rise (or demise) of other seasonal sports competing for the same talent and audience base. Nonetheless, we feel that of these multiple factors, it is social stratification that lies most fundamentally at the heart of the matter. The extent to which an elite cultural practice like cricket was shared with or shielded from the general population was a direct result of elites' own sense of their place atop the social hierarchy. Had American elite cricketers felt less anxious about their social position, for example, they might have popularized the sport along the same lines as baseball (or golf and tennis).

\section{CONCLUSION}

\section{WHAT MIGHT WE LEARN FROM THE GLOBAL DIFFUSION OF CRICKET?}

We began this project with both substantive and theoretical questions in mind. Theoretically, we questioned the propensity of diffusion models to emphasize solely structural or exclusively cultural factors in the adoption process. That is, we wondered what, besides cultural affinity or network ties, accounts for the successful diffusion of a cultural practice from one society to another. Furthermore, we wondered what sociological theories of diffusion might gain by considering examples where diffusion was initially successful and then failed. Substantively speaking, we wondered why Canadians were not more enthusiastic about cricket given their strong cultural and political connections to England. This case seemed especially compelling in light of all the recent attention put on globalization and the would-be homogenization of world culture. What might the global history of cricket tell us about other potentially diffusible phenomena, particularly those that bear with them such strong relations to their country of origin?

With regard to cricket, we have identified several factors that seem closely related to variance in the success or failure of the sport in countries connected to the former British Empire. Beyond merely being exposed to the sport, settler societies needed to dedicate time and resources to nurturing indigenous support for the game. In other words, some portion of the population needed to devote itself to playing cricket (adoption), and some larger portion needed to be persuaded to care about it (acculturation). We note, too, that in the final, acculturation phase, the game appears to take on cultural valence unique to its people; in other words, it becomes part of the national patrimony, as opposed to a simple cultural import. In some colonial societies, for example, cricket developed as a way for settlers to prove their "Britishness," whereas in others, excellence at the game offered an opportunity for natives literally to beat the British at their own game. In the unique case of Australia, moreover, both elements combined into a fiercely nationalist but ultimately anglophilic love of the game.

More specifically, cricket was elevated to a national sporting pastime in societies where players and audiences were recruited from an array of social class backgrounds. In the United States and Canada, elites literally took cricket from the public sphere and confined it to their own social circles. This contrasts sharply with the history of cricket in the other colonies of the British Empire, where racial inequality, selective access to secondary education, and quasifeudal land allocation systems limited socioeconomic mobility. Those at the top of the economic system felt comfortable sharing their pastimes with the masses. Elites actively promoted and stuck with the game even after it became a sport practiced by low-status members of society. Thus, cricket became a popular sport played and enjoyed by all.

The very nature of the game itself, we have argued, was also an important part of the diffusion process: Cricket's strong identification with English imperialism made it attractive to both those who cherished the "mother country" and those who wished for nothing more than symbolically to defeat it. The sport's absence of physical contact, its strictures on rowdiness, and its low costs when played informally - bats, balls, and stumps can all be handmade-also contributed to its diffusion throughout much of the British Commonwealth.

We argue, furthermore, that it was the relative social mobility of mid-nineteenth-century American and Canadian society that prompted elites there to protect their cultural patrimony from the masses. This reasoning is comparable to that offered in explanation of the development 
of other forms of exclusionary cultural practice. According to Elias ([1939] 2000), for example, economic elites in late medieval Europe responded to the status pressures of defeudalization by promoting specific repertoires of etiquette by which they might differentiate themselves from the masses. In a more modern context, social elites in late-nineteenth-century Boston responded to similar status pressure by cultivating tastes for European music, art, and theater, as well as creating exclusive social venues in which to partake of them (DiMaggio 1982; Levine 1988; see Dunae 1981 and Gruneau 1983 for comparable analyses of Canada). Seen from this perspective, equality of economic opportunity promoted elite efforts to limit equality of cultural opportunity.

In the big picture, the history of cricket highlights an important feature of global culture more generally. Global cultural diffusion relies not simply on the transmission of cultural "signals" from place to place, but also on: (1) The relationship among different categories of recipients in host societies, particularly with respect to the distribution of social status among them, as well as the equality of opportunity to gain such status; and (2) the ability of some groups of recipients to dominate or otherwise limit access to cultural imports, thereby "capturing" such imports for themselves. While limiting access to high-status goods might only make them more attractive to lower-status consumers, there is a point of diminishing returns at which popular interest will peak and subsequently subside. Thus, for example, ownership of raw commodities like diamonds and pearls may become more prevalent as their price increases; not so for cultural practices that are more easily "protected."

Access to cricket in the United States and Canada was "overprotected," so to speak, thus forestalling its acculturation as a "hegemonic sports culture." In point of fact, any cultural good or practice can be so protected if it requires: (a) repeated points of contact, as in the case of anything that must be learned, replenished, or maintained; (b) extensive gatekeeping, as with cultural practices that are sufficiently sophisticated, esoteric, or non-obvious as to require explanation, instruction, or prior evaluation by specialists; and/or (c) widespread collaboration, as with "social" goods such as musical performances or team sports that require interaction with groups of competitors and/or co-participants. While nearly anything can be had for the right price, some cultural commodities are simply too "social" to be assimilated without ready and consistent support. Thus, the global diffusion of cultural practices requires not only that those in "receiver" societies show interest in these practices, but that the resources necessary to adopt them are widely available. This access often hinges on indigenous elites' desire and ability to keep such resources to themselves.

We see here an important dimension of the cross-cultural diffusion process otherwise overlooked; something we have called, borrowing a term from Rogers (1995), heterophilous, or topdown, diffusion. While popular tastes and consumer agency play a large role in the reception and adoption of easily accessible foreign cultural goods and practices-so-called homophilous paths to successful diffusion - indigenous elites sometimes play an even more important role in casting imported cultural goods or practices as high- or low-brow items. Elites' ability to control access to such goods has significant ramifications for popular retention thereof. Presumably, cross-national variation in the diffusion of many such items can be explained in exactly this fashion. Thus, it may be that future studies of cross-national cultural diffusion should pay as much attention to elite as to popular tastes. So, too, should the institutionalization of such tastes across public and private venues be of increasing concern to those interested in the topic. Neither value nor venue are a priori features of cultural imports, we argue. Diffusion scholars must then strive for renewed sensitivity toward the culturally specific meanings of the items or practices being diffused, as well as toward the social strata associated with and/or in control of access to their use.

Jason Kaufman is John L. Loeb Associate Professor of the Social Sciences at Harvard University, where he teaches comparative/historical sociology, politics, and culture in the Department of Sociology. His current research focuses on the comparative political development of the United States and Canada. A related project seeks to explain Vermont's unusual political trajectory from anti-statist Republican stronghold to bastion of the radical left. He is author of For The Common Good? American Civic Life and the Golden Age of Fraternity, as well as articles on urban politics and fiscal policy; AIDS/HIV policy; ethno-religious and labor fraternities; civilian 
militias; and cultural capital and educational attainment.

Orlando Patterson is John Cowles Professor of Sociology at Harvard. His work addresses, in comparative/historical terms, the interactive causal role of culture and seeks to unravel the neglected problem of continuity. Applications include the nature and dynamics of slavery and resistance; the construction and diffusion of freedom, globalization, and reggae music; the sources and problems of ethnic identity; and the persistence of poverty and gender relations in the Caribbean and America. He is currently completing a book on the meaning and experience of freedom in America. Recent publications include "Culture and Continuity" in Matters of Culture: Cultural Sociology In Practice, edited by J. Mohr and R. Friedland, as well as papers on ancient helotic slavery and ethnic stratification in England and the Americas.

\section{REFERENCES}

Adelman, Melvin L. 1986. A Sporting Time: New York City and the Rise of Modern Athletics, 1820-1870. Urbana, IL: University of Illinois Press.

Allen, David Rayvern. 1990. Cricket: An Illustrated History. Oxford, England: Phaidon Press.

Appadurai, Arjun. 1996. Modernity at Large: Cultural Dimensions of Globalization. Minneapolis, MN: University of Minnesota Press. Baltzell, E. Digby. [1979] 1996. Puritan Boston and Quaker Philadelphia. New Brunswick, NJ: Transaction Publishers.

Barney, Robert. 1992. "In Search of a Canadian Cooperstown: The Future of the Canadian Baseball Hall of Fame." Nine: A Journal of Baseball History and Social Policy 1.

Barney, Robert. 1989. "Diamond Rituals: Baseball in Canadian Culture.' Pp. 1-21 in Baseball History 2: An Annual of Original Baseball Research, edited by Peter Levine. Westport, CT: Meckler.

Beckles, Hilary McD. 1998a. The Development of West Indies Cricket, vol. 1 The Age of Nationalism. Barbados: Press of the University of the West Indies.

-, ed. 1998b. A Spirit of Dominance: Cricket and Nationalism in the West Indies. Barbados: Canoe Press.

Beckles, Hilary McD and Brian Stoddart, eds. 1995. Liberation Cricket: West Indies Cricket Culture. Manchester, England: Manchester University Press.

Bhabha, Homi. 1994. The Location of Culture. London, England: Routledge Press.

Boller, Kevin. 1994a. "International Cricket: Launched by a Hoax." The Canadian Cricketer $22: 23$.

1994b. "The 49th Parallel Divide: The
Story of Canada and the United States at Cricket." The Canadian Cricketer 22: 24-25.

Bose, Mihir. 1990. A History of Indian Cricket. London, England: Deutsch.

Bouchier, Nancy and Robert Barney. 1988. "A Critical Examination of a Source on Early Ontario Baseball: The Reminiscence of Adam E. Ford." Journal of Sport History 15:75-90.

Bourdieu, Pierre. 1978. "Sport and Social Class." Social Science Information 17:819-40.

Brookes, Christopher. 1978. English Cricket: The Game and Its Players Throughout the Ages. London, England: Weidenfeld and Nicholson.

Burt, Ronald. 1987. "Social Contagion and Innovation: Cohesion vs. Structural Equivalence.” American Journal of Sociology 92:1287-335.

Buskens, Vincent and Kazuo Yamaguchi. 1999. “A New Model for Information Diffusion in Heterogeneous Social Networks." Sociological Methodology 29:281-325.

Cashman, Richard. 1979. "The Phenomenon of Indian Cricket.” Pp. 180-204 in Sport in History: The Making of Modern Sporting History, edited by Richard Cashman and Michael McKernan. Queensland, Australia: University of Queensland Press.

1980. Patrons, Players and the Crowd: The Phenomenon of Indian Cricket. New Delhi, India: Orient Longman.

. 1984. 'Ave a Go, Yer Mug! Australian Cricket Crowds from Larrikin to Ocker. Sydney, Australia: Collins.

_. 1998a. "Australia." The Imperial Game: Cricket, Culture and Society, edited by Brian Stoddart and Keith A. P. Sandiford. Manchester, England: Manchester University Press.

-. 1998b. "The Subcontinent." The Imperial Game: Cricket, Culture and Society, edited by Brian Stoddart and Keith A. P. Sandiford. Manchester, England: Manchester University Press.

Chadwick, Henry. 1868. American Chronicle of Sports and Pastimes 1:52.

Clark, Manning. 1995. A Short History of Australia. 4th rev. ed. Victoria, Australia: Penguin Books.

Clemens, Elisabeth S. and James M. Cook. 1999. "Politics and Institutionalism: Explaining Durability and Change." Annual Review of Sociology 25:441-66.

Coakley, J. J. 1998. Sport in Society. St. Louis, MO: Mosby.

Cole, Robert E. 1989. Strategies for Learning: SmallGroup Activities in American, Japanese, and Swedish Industry. Berkeley, CA: University of California Press.

Coleman, James S., Elihu Katz, and Herbert Menzel. 1966. Medical Innovation: A Diffusion Study. Indianapolis, IN: Bobbs-Merrill.

Connell, R. W. and T. H. Irving. 1980. Class Structure 
in Australian History: Documents, Narrative and Argument. Melbourne, Australia: Longman Cheshire.

Cozier, Tony. 1978. The West Indies: Fifty Years of Test Cricket.Brighton, England: Angus and Robertson.

Crane, Diana. 2000. Fashion and Its Social Agendas: Class, Gender, and Identity in Clothing. Chicago, IL: University of Chicago Press.

“Cricket." 1907. New York Times, Sept. 21.

DiMaggio, Paul J. 1982. "Cultural Entrepreneurship in Nineteenth-Century Boston." Media, Culture, and Society 4:33-50.

DiMaggio, Paul J. and Walter W. Powell. 1983. "The Iron Cage Revisited: Institutional Isomorphism and Collective Rationality in Organizational Fields." American Sociological Review 48:147-60.

Dobbin, Frank and John R. Sutton. 1998. "The Strength of a Weak State: The Rights Revolution and the Rise of Human Resources Management Divisions." American Journal of Sociology 104: 441-76.

Dunae, P. A. 1981. Gentlemen Emigrants: From the British Public Schools to the Canadian Frontier. Vancouver, Canada: Douglas and McIntyre.

Dunning, Eric and Kenneth Sheard. 1979. Barbarians, Gentlemen and Players: A Sociological Study of the Development of Rugby Football. New York: New York University Press.

Elias, Norbert. [1939] 2000. The Civilizing Process. Rev. ed. Oxford, England: Blackwell.

Frye, Northrop. 1971. The Bush Garden: Essays on the Canadian Imagination. Toronto, Canada: Anansi.

"The Game Was Stopped." 1888. New York Times, May 21.

Gottdiener, M. 1985. "Hegemony and Mass Culture: A Semiotic Approach." American Journal of Sociology 90:979-1001.

Granovetter, Mark and Roland Soong. 1983. "Threshold Models of Diffusion and Collective Behavior." Journal of Mathematical Sociology 9: 165-79.

Gruneau, Richard. 1983. Class, Sports, and Social Development. Amherst, MA: University of Massachusetts Press.

Guillén, Mauro F. 1994. Models of Management: Work, Authority, and Organization in a Comparative Perspective. Chicago, IL: University of Chicago Press.

2001. The Limits of Convergence: Globalization and Organizational Change in Argentina, South Korea, and Spain. Princeton, NJ: Princeton University Press.

Gunaratnam, Visva. 1993. "I Have a Dream." The Canadian Cricketer 21: 11.

Hall, John E. and R. O. McCulloch. 1895. Sixty Years of Canadian Cricket. Toronto, Canada: Bryant.

Harvard College. 1889. Annual Reports of the
President and Treasurer of Harvard College, 1887-1888. Cambridge, MA: Harvard College.

Headlam, Cecil. 1903. Ten Thousand Miles Through India and Burma: An Account of the Oxford University Authentics' Cricket Tour with Mr. K. J. Key in the Year of the Durbar. London, England: Dent.

Hickie, Thomas V. 1993. They Ran with the Ball: How Rugby Football Began in Australia. Melbourne, Australia: Longman Cheshire.

Hughes, Robert. 1986. The Fatal Shore: The Epic of Australia's Founding. New York: Vintage.

Humber, William. 1995. Diamonds of the North: A Concise History of Baseball in Canada. Toronto, Canada: Oxford University Press.

James, C.L.R. 1963. Beyond a Boundary. London, England: Hutchinson.

Kaufman, Jason. 2002. For the Common Good? American Civic Life and the Golden Age of Fraternity. New York: Oxford University Press.

Kirsch, George. 1991. "Massachusetts Baseball and Cricket, 1840-1870." Pp. 1-15 in Sports in Massachusetts: Historical Essays, edited by Ronald Story. Westfield, MA: Institute for Massachusetts Studies, Westfield State College.

Kirsch, George. 1989. The Creation of American Team Sports: Baseball and Cricket, 1838-72. Urbana, IL: University of Illinois Press.

Lester, John A., ed. 1951. A Century of Philadelphia Cricket. Philadelphia, PA: University of Pennsylvania Press.

Levine, Lawrence W. 1988. Highbrow/Lowbrow: The Emergence of Cultural Hierarchy in America. Cambridge, MA: Harvard University Press.

Levine, Peter. 1985. A. G. Spalding and the Rise of Baseball: The Promise of American Sport. New York: Oxford University Press.

Lillrank, Paul. 1995. "The Transfer of Management Innovations from Japan." Organization Studies 16:971-89.

Lipset, Seymour Martin. 1996. American Exceptionalism: A Double-Edged Sword. New York: Norton.

Maguire, Joseph. 1999. Global Sport: Identities, Societies, Civilizations. Oxford, England: Polity Press.

Malcolm, Dominic. 2001. “'It's Not Cricket': Colonial Legacies and Contemporary Inequalities." Journal of Historical Sociology 14: 253-75.

Mandle, W. F. 1973. "Games People Played: Cricket and Football in England and Victoria in the Late Nineteenth Century." Historical Studies 15(60): 511-535.

Mangan, J. A. 1986. The Games Ethic and Imperialism: Aspects of the Diffusion of an Ideal. London, England: Frank Cass.

Markovits, Andrei S. and Steven L. Hellerman. 2001. Offside: Soccer and American Exceptionalism. Princeton, NJ: Princeton University Press. 
Marsden, Peter and Joel Podolny. 1990. "Dynamic Analysis of Network Diffusion Processes." Social Networks Through Time, edited by J. Weesie and H. Flap. Utrecht, Netherlands: ISOR.

Melville, Tom. 1998. The Tented Field: A History of Cricket in America. Bowling Green, IN: Bowling Green State University Popular Press.

Merrett, Christopher and John Nauright. 1998. "South Africa." Pp. 55-78 in The Imperial Game: Cricket, Culture and Society, edited by Brian Stoddart and Keith A. P. Sandiford. Manchester, England: Manchester University Press.

Metcalfe, Alan. 1987. Canada Learns to Play: The Emergence of Organized Sport, 1807-1914. Toronto, Canada: McClelland and Stewart.

Meyer, John and Michael Hannan, eds. 1979. National Development and the World System: Educational, Economic and Political Change, 1950-1970. Chicago, IL: University of Chicago Press.

Miller, Toby, Geoffrey Lawrence, Jim McKay, and David Rowe. 2001. Globalization and Sport, London, England: Sage Publications.

Mizruchi, Mark S. and Lisa C. Fein. 1999. "The Social Construction of Organizational Knowledge: A Study of the Uses of Coercive, Mimetic, and Normative Isomorphism." Administrative Science Quarterly 44: 653-83.

Molotch, Harvey, William Freudenburg, and Krista E. Paulsen. 2000. "History Repeats Itself, but How? City Character, Urban Tradition, and the Accomplishment of Place." American Sociological Review 65:791-823.

Mrozek, Donald J. 1983. Sport and American Mentality, 1880-1910. Knoxville, TN: University of Tennessee Press.

Nandy, Ashis. 2000. The Tao of Cricket: On Games of Destiny and Destiny of Games. New Delhi, India: Oxford University Press.

Palloni, Alberto. 2001. "Diffusion in Sociological Analysis." Pp. 67-114 in Diffusion Processes and Fertility Transition: Selected Perspectives, edited by John B. Casterline. Washington D.C.: National Academy Press.

Patterson, Orlando. 1994. "Ecumenical America: Global Culture and the American Cosmos." World Policy Journal 11:103-17.

-Patterson, Orlando. 1995. "The Ritual of Cricket." Pp. 141-47 in Liberation Cricket, edited by Hilary McD Beckles and Brian Stoddart. Kingston, Jamaica: Ian Randle Publishers.

Penn, Alan. 1999. Targeting Schools: Drill, Militarism and Imperialism. London, England: Woburn Press.

Perera, S. S. 1998a. The Janashakthi Book of Sri Lanka Cricket, 1832-1996. Colombo: Janashakthi Insurance.

_ 1998b. "Notes on Sri Lanka's Cricket Heritage." Crosscurrents: Sri Lanka and Australia at Cricket, edited by Michael Roberts and Alfred James. Petersham, Australia: Walla Walla Press.

“The Philadelphia Cricketers." 1884. New York Times, July 15 .

Pollard, Jack. 1987. The Formative Years of Australian Cricket, 1803-1893. North Ryde, Australia: Angus and Robertson.

Redmond, Gerald. 1979. "Some Aspects of Organized Sport and Leisure in Nineteenth-Century Canada." Loisir et société/Society and Leisure 2:73-100.

Reese, T. W. 1927. New Zealand Cricket, 1814-1914. Christchurch, New Zealand: Simpson and Williams.

Robertson, R.1992. Globalization: Social Theory and Global Culture. London: Sage Publications.

Rogers, Everett M. 1995. Diffusion of Innovations. 4th ed. New York: Free Press.

Ryan, Greg. 1998. "New Zealand." Pp. 93-115 in The Imperial Game: Cricket, Culture and Society, edited by Brian Stoddart and Keith A. P. Sandiford. Manchester, England: Manchester University Press.

Sandiford, Keith A. P. 1994. Cricket and the Victorians. Aldershot, England: Scholar Press.

—. 1998a. "England." Pp. 9-33 in The Imperial Game: Cricket, Culture and Society, edited by Brian Stoddart and Keith A. P. Sandiford. Manchester, England: Manchester University Press.

-. 1998b. "Introduction." Pp. 1-8 in The Imperial Game: Cricket, Culture and Society, edited by Brian Stoddart and Keith A. P. Sandiford. Manchester, England: Manchester University Press.

. 1998c. Cricket Nurseries of Colonial Barbados: The Elite Schools, 1865-1966. Barbados: Press of the University of the West Indies.

Sayen, Henry. 1956. A Yankee Looks At Cricket. London, England: Putnam.

Schudson, Michael. 1989. "How Culture Works: Perspectives from Media Studies on the Efficacy of Symbols." Theory and Society 18:153-80.

Smith, Ronald A. 1988. Sports and Freedom: The Rise of Big-Time College Athletics. New York: Oxford University Press.

Spalding, Albert G. [1911] 1992. America's National Game. Lincoln, NE: University of Nebraska Press.

Starr, Paul. 1989. "The Meaning of Privatization." Pp. 15-48 in Privatization and the Welfare State, edited by Sheila Kamerman and Alfred Kahn. Princeton, NJ: Princeton University Press.

Steen, Rob. 1999. The Official Companion to the 1999 Cricket World Cup. London: Boxtree.

Stoddart, Brian. 1988. "Sport, Cultural Imperialism, and Colonial Response in the British Empire." Comparative Studies in Society and History 30: 649-73.

1998a. "West Indies." The Imperial Game: 
Cricket, Culture and Society, edited by Brian Stoddart and Keith A. P. Sandiford. Manchester, England: Manchester University Press.

- 1998b. "Other Cultures." The Imperial Game: Cricket, Culture and Society, edited by Brian Stoddart and Keith A. P. Sandiford. Manchester

Stoddart, Brian and Keith A. P. Sandiford, eds. 1998. The Imperial Game: Cricket, Culture and Society. Manchester, England: Manchester University Press.

Stone, Derrick I. and Donald S. Garden. 1978. Squatters and Settlers. Sydney, Australia: Reed.

Strang, David. 1990. "From Dependency to Sovereignty: An Event History Analysis of Decolonization 1870-1987." American Sociological Review 55: 846-60.

Strang, David and John Meyer. 1993. "Institutional Conditions for Diffusion." Theory and Society 22:487-511.

Strang, David and Sarah Soule. 1998. "Diffusion in Organizations and Social Movements: From Hybrid Corn to Poison Pills." Annual Review of Sociology 24:265-90.

Townsend, Kim. 1996. Manhood at Harvard: William James and Others. Cambridge, MA: Harvard University Press.

Vaille, F. O. and H. A. Clark, eds. 1875. The Harvard
Book: A Series of Historical, Biographical, and Descriptive Sketches. Cambridge: Welch, Bigelow. Van den Bulte, Christophe and Gary L. Lilien. 2001. "Medical Innovation Revisited: Social Contagion versus Marketing Effort." American Journal of Sociology 106:1409-35.

Warner, Sir Pelham. 1950. Gentlemen v. Players, 1806-1949. London: George G. Harrap.

Watson, James L. 2002. "Transnationalism, Localization, and Fast Foods in East Asia." Pp. 222-32 McDonaldization: The Reader, edited by George Ritzer. Thousand Oaks, CA: Pine Forge Press.

Wejnert, Barbara. 2002. "Integrating Models of Diffusion of Innovations: A Conceptual Framework." Annual Review of Sociology 28:297-326.

Williams, Jack. 2001. Cricket and Race. Oxford, England: Berg.

Winch, Jonty. 1983. Cricket's Rich Heritage : A History of Rhodesian and Zimbabwean Cricket, 1890-1982. (Bulawayo, Zimbabwe : Books of Zimbabwe).

Wise, S. F. 1989. "Sport and Class Values in Old Ontario and Quebec." Pp. 107-129 in Sports in Canada: Historical Readings, edited by Morris Mott. Toronto, Canada: Copp, Clark, Pitman. 